\title{
GROUND WATER QUALITY ASSESSMENT BY USING GEOGRAPHICAL INFORMATION SYSTEM AND WATER QUALITY INDEX: A CASE STUDY OF CHOKERA, FAISALABAD, PAKISTAN
}

\author{
Afif Ahmed*, Abdul Nasir, Sana Basheer, Ch. Arslan, Shafiq Anwar \\ Department of Structures and Environmental Engineering, University of Agriculture, Faisalabad, Pakistan \\ *Corresponding Author's Email: afifahmed07@gmail.com
}

This is an open access article distributed under the Creative Commons Attribution License, which permits unrestricted use, distribution, and reproduction in any medium, provided the original work is properly cited.

\section{ARTICLE DETAILS}

\section{Article History:}

Received 24 November 2018 Accepted 25 December 2018 Available online 28 January 2019

\section{ABSTRACT}

Water quality is considered as a major issue in mega cities of developing countries. The city of Faisalabad has over 4 million population. Groundwater is the main source of drinking water in Faisalabad. The groundwater quality should be regularly monitored in order to cope with the drinking water quality issues. An attempt has been made to understand the groundwater quality by using water quality index (WQI) at Chokera area, Faisalabad, Pakistan. It is a technique of rating water quality, is an effective tool to assess spatial and temporal changes in groundwater quality. Sixty groundwater samples were collected and analyzed for physico-chemical parameters using standard method of analysis. From the data obtained, the water quality index was calculated by adopting the method developed by Tiwari and Mishra. Water quality index rating was carried out to quantify overall ground water quality status of the area. The WQI index of the same has been calculated and the values ranged from 73 to 272 . The WQI values from present study indicate the very poor water quality in the area. The analysis reveals the fact that the groundwater of the Chokera area needs a degree of treatment before consumption and needs to be protected from further contamination.

\section{KEYWORDS}

Groundwater quality, Water quality index, Waste water impact, GIS

\section{INTRODUCTION}

Pakistan's population at the time of independence was only 32.5 million and increased rapidly up to 184.35 million in 2013. This increasing trend in population poses serious threats on limited natural resources of country [1].

Depletion and deterioration of surface and ground water resources made Pakistan a water deficit country. This situation is due to shortage of surface storage and shift of fresh water use from agriculture to domestic as well as industrial use [2].

Improper disposal system of domestic and industrial wastewater causing serious threats for water resources and human health [3]. This situation is more critical in those urban and industrial areas where ground water deterioration caused various water-borne diseases and irremediable damage to environment.

Groundwater is an important source of water supply throughout the world. Groundwater occurs almost everywhere beneath the earth surface not in a single widespread aquifer but in thousands of local aquifer systems and compartments that have similar characters. Knowledge of the occurrence, replenishment and recovery of groundwater has special significance in arid and semi-arid regions due to discrepancy in monsoonal rainfall, insufficient surface waters and over drafting of groundwater resources.

The ground water quality is very important to the community, therefore it is important to ensure its high quality at all time so that the consumer's health is not compromised. Groundwater resources are affected in principle by three major activities. First of these activities is excessive use of fertilizers and pesticides in agricultural areas. The second one is untreated/partially treated wastewater to the environment. Finally, excessive pumping and improper management of aquifers [4]. The activity of solid waste disposal in open un-engineered landfill is the one of the factors that cause the ground water pollution due to lack of pollution control interventions such as water proof layer, leachate treatment pond, monitoring wells, etc. [5].

Due to improper wastewater management, the wastewater seeps into the ground along with many chemicals and heavy metals. The same water we pump for drinking which is a main cause of many diseases. Besides, this water is also used for irrigation near the cities without any treatment. In this way, these chemicals and metals enter into our food chain through soil and crops resulting into many diseases such as blood pressure, liver and urinal cancer, blindness, skin cancer and mental stress. It is estimated that about $40 \%$ of diseases in Pakistan are caused by drinking of polluted water [6].

Water quality index (WQI) is defined as a rating reflecting the composite influence of different water quality parameters. A previous researcher has firstly used the concept of WQI, which was further developed by another researcher and improved by Deininger (Scottish Development Department, 1975) [7,8]. WQI is most effective tools to communicate information on the quality of any water body. WQI is a mathematical equation used to transform large number of water quality data into a 
single number. WQI is one of the most effective tools to communicate information on the quality of water to the concerned citizens and policymakers. The advent of satellite technology and geographical information system (GIS) has made it very easy to map the sampling area. GIS has wide application in water quality mapping using which informative and userfriendly maps can be obtained [9].

The water quality of the study area was determined for all samples using the weighted arithmetic index method [10]. In this method, the fourteen important parameters such as pH, EC, TDS, TSS, DO, Carbonates, Bicarbonates, Chloride Contents, Arsenic (As), Lead (Pb), Cadmium (Cd), Copper ( $\mathrm{Cu})$, Chromium ( $\mathrm{Cr}$ ) and Zinc (Zn) were taken for assessment.

\section{MATERIAL AND METHODS}

\subsection{Study Area}

The study area was selected beside Chokera Treatment Plant in $2 \mathrm{~km}$ radius around the treatment plant in Faisalabad.

Faisalabad is located in the Rachna doab i.e. the area between the rivers Ravi and Chenab. The total geographical area of the Faisalabad district is $5,856 \mathrm{~km}^{2}$ with a total population of more than 4 million.

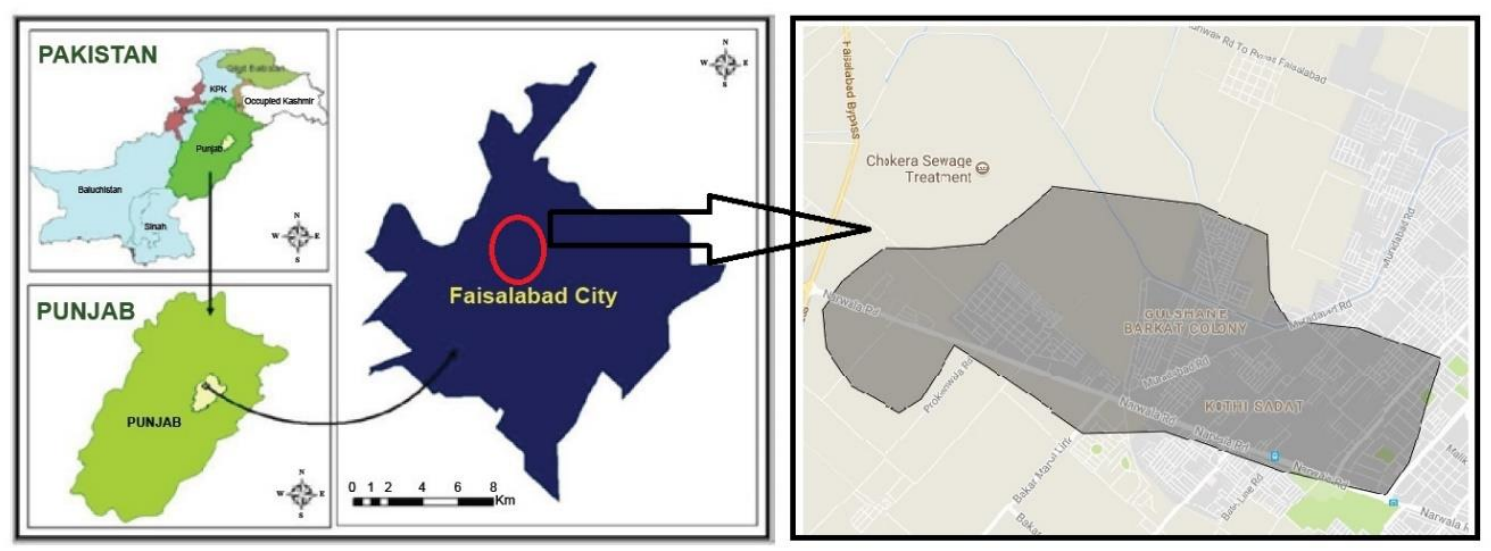

Figure 1: Study Area

\subsection{Sampling Plan}

Groundwater samples were collected randomly throughout the study area on both sides of the Chokera Treatment Plant from 60 different points. GPS coordinates were taken at each sampling point. Total 60 groundwater samples were collected. Groundwater samples were collected from pumps, motors and hand pumps. The samples were collected in PVC bottles. The quantity of each sample was $500 \mathrm{ml}$. For groundwater sampling PVC bottles and GPS meter was used.

\subsection{Water Quality Index (WQI)}

WQI is calculated from the point of view of the suitability of groundwater for human consumption. Water quality index is one of the most effective tools to communicate information on the quality of any water body. WQI is a mathematical equation used to transform large number of water quality data into a single number. It is simple and easy to understandable for decision makers about quality and possible uses of any water body. It serves the understanding of water quality issues by integrating complex data and generating a score that describes water quality status.

To develop the Water Quality Index (WQI) the following four steps were performed

\section{Step I}

Each parameter will be assigned a weightage and then the Relative weightage $W_{i}$ for each parameter will be found by formula

$$
W_{i}=\frac{w_{i}}{\sum_{i=1}^{n} w_{i}}
$$

Where,

$W_{i}=$ Relative Weightage

$w_{i}=$ Weightage of each Parameter

$\mathrm{n}=$ No. of Parameters

\section{Step II}

Quality Rating will be found by following Formula

$$
Q_{i}=\frac{c_{i}}{s_{i}} \times 100
$$

Where,

$Q_{i}=$ Quality Rating

$c_{i}=$ Concentration of each parameter in each water sample

$s_{i}=$ Permissible Value of each parameter

Step III

Sub Index will be found by following formula

$$
S I_{i}=W_{i} \times Q_{i}
$$

Where,

$S I_{i}=$ Sub Index of ith parameter

$Q_{i}=$ Quality Rating of $\mathrm{i}^{\text {th }}$ parameter

Step IV

Water Quality Index will be found by using formula

$$
W Q I=\sum_{i=1}^{n} S I_{i}
$$

Table 1: Relative Weights of Parameters for WQI

\begin{tabular}{|c|c|c|c|c|}
\hline Sr. No. & Parameter & WHO Standard & Weight (wi) & Relative Weight (Wi) \\
\hline 1 & $\mathrm{pH}$ & $6.5-8.5$ & 3 & 0.058 \\
\hline 2 & EC & $2 \mathrm{dS} / \mathrm{m}$ & 2 & 0.058 \\
\hline 3 & TDS & $1000 \mathrm{mg} / \mathrm{l}$ & 0.038 \\
\hline 4 & TSS & $500 \mathrm{mg} / \mathrm{l}$ & 2 & 0.038 \\
\hline 5 & DO & $5 \mathrm{mg} / \mathrm{l}$ & 0.038 \\
\hline 6 & Carbonates & $75 \mathrm{mg} / \mathrm{l}$ & 3 & 0.038 \\
\hline 7 & Bicarbonates & $250 \mathrm{mg} / \mathrm{l}$ & 0.058 \\
\hline 8 & Chloride Contents & $250 \mathrm{mg} / \mathrm{l}$ & 5 & 0.096 \\
\hline
\end{tabular}




\begin{tabular}{|c|c|c|c|c|}
\hline 9 & Arsenic (As) & $0.01 \mathrm{mg} / \mathrm{l}$ & 5 & 0.096 \\
\hline 10 & Lead (Pb) & $0.01 \mathrm{mg} / \mathrm{l}$ & 5 & 0.096 \\
\hline 11 & Cadmium (Cd) & $0.05 \mathrm{mg} / \mathrm{l}$ & 5 & 0.096 \\
\hline 12 & Copper (Cu) & $0.05 \mathrm{mg} / \mathrm{l}$ & 5 & 0.096 \\
\hline 13 & Chromium (Cr) & $0.05 \mathrm{mg} / \mathrm{l}$ & 5 & 0.096 \\
\hline 14 & Zinc (Zn) & $0.05 \mathrm{mg} / \mathrm{l}$ & 5 & $\mathbf{5 = 5 2}$ \\
\hline
\end{tabular}

Table 2: WQI Range and Water Quality

\begin{tabular}{|c|c|c|}
\hline Sr. No. & WQI Range & Water Quality \\
\hline 1 & $<50$ & Excellent Water \\
\hline 2 & $50-100$ & Good Water \\
\hline 3 & $100-200$ & Poor Water \\
\hline 4 & $200-300$ & Very Poor Water \\
\hline 5 & $>300$ & Unsuitable for Drinking \\
\hline
\end{tabular}

\section{RESULTS AND DISCUSSION}

\section{$3.1 \mathrm{pH}$}

It plays an important role in clarification process and disinfection of drinking water. For effective disinfection with chlorine, the $\mathrm{pH}$ should preferably be less than eight, however, lower-pH water $(<7)$ is more likely to be corrosive. Failure to minimize corrosion can result in the contamination of drinking water and adverse effect on its taste and appearance. World Health Organization (WHO) has pre-scribed permissible limit of $\mathrm{pH}$ to be 6.5-8.5. The $\mathrm{pH}$ value of groundwater samples in the present study has been analyzed and it lies in the range 6.68.8 (Figure 2).

\section{Variation of $\mathrm{pH}$ at Different Locations}

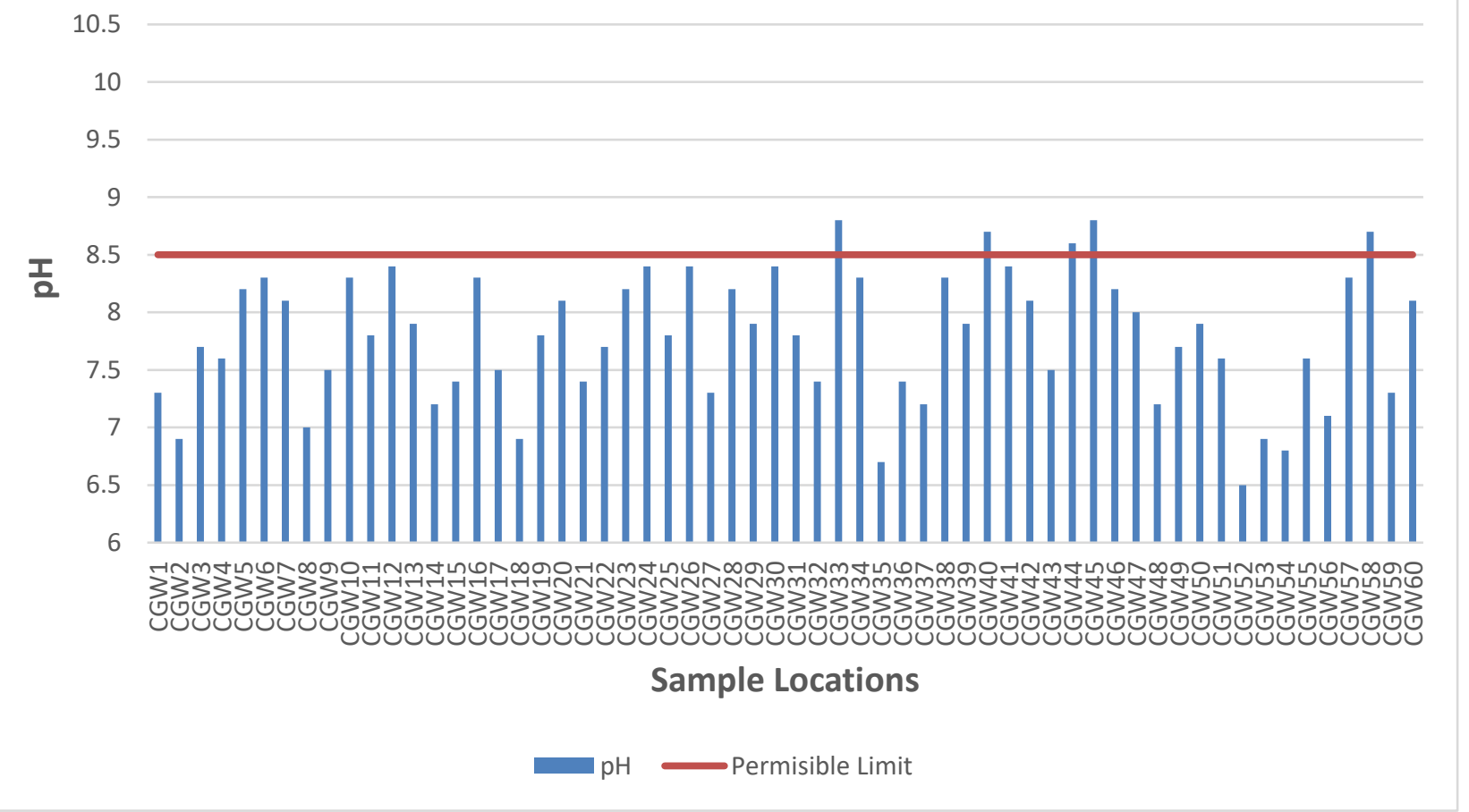

Figure 2: Variation of $\mathrm{pH}$ at Different Locations 


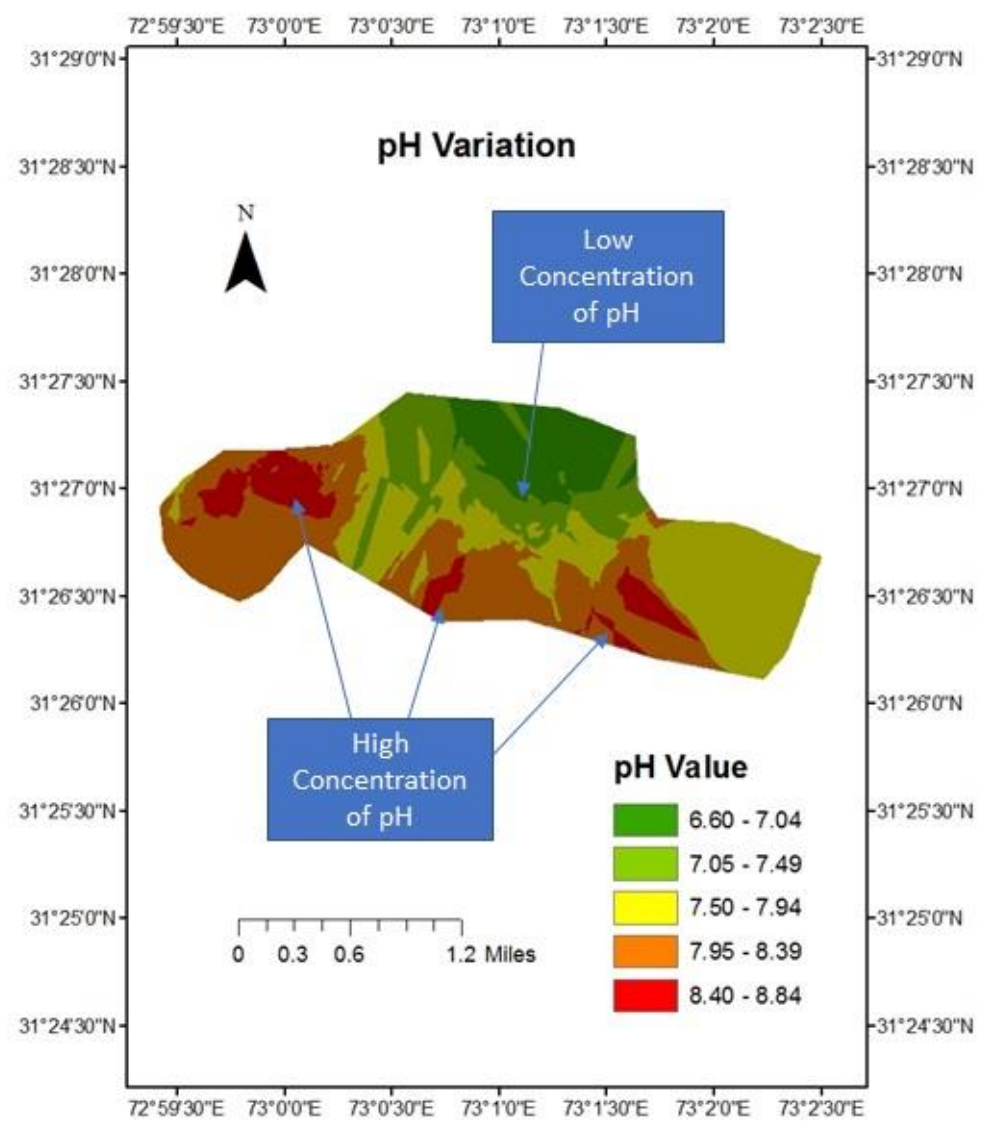

Figure 3: Variation of pH in Different Groundwater Samples

\subsection{TDS}

The presence of dissolved solids in water may affect its taste. The palatability of drinking water has been rated by panels of tasters in relation to its TDS level as follows: excellent (less than $300 \mathrm{mg} / \mathrm{l}$ ), good (300-600 $\mathrm{mg} / \mathrm{l})$; fair $(600-900 \mathrm{mg} / \mathrm{l})$, poor $(900-1,200 \mathrm{mg} / \mathrm{l})$ and unacceptable $(>1,200 \mathrm{mg} / \mathrm{l})$. WHO has prescribed $1000 \mathrm{mg} / \mathrm{L}$ as the permissible limit for TDS for the water to be used for drinking purpose. In present study, the TDS concentration of analyzed samples lies in the range of $128-3010 \mathrm{mg} / \mathrm{L}$ (Figure 4).

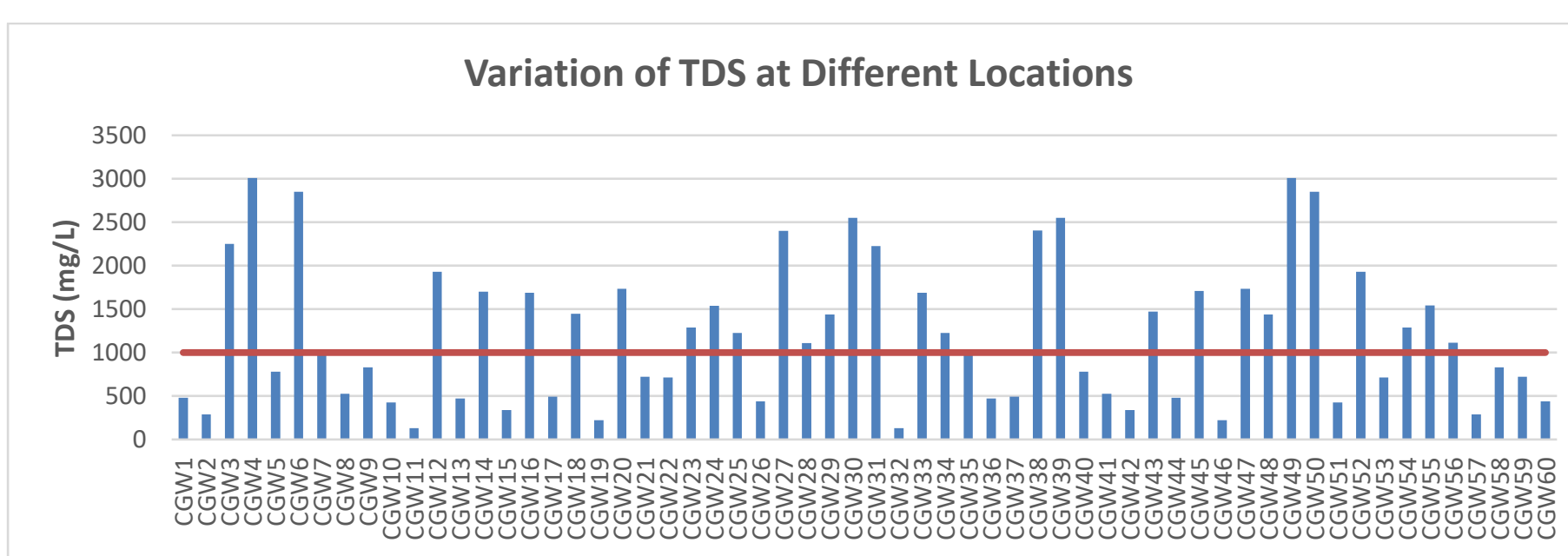

Sample Locations

TDS Permisible Limit

Figure 4: Variation of TDS at Different Locations 


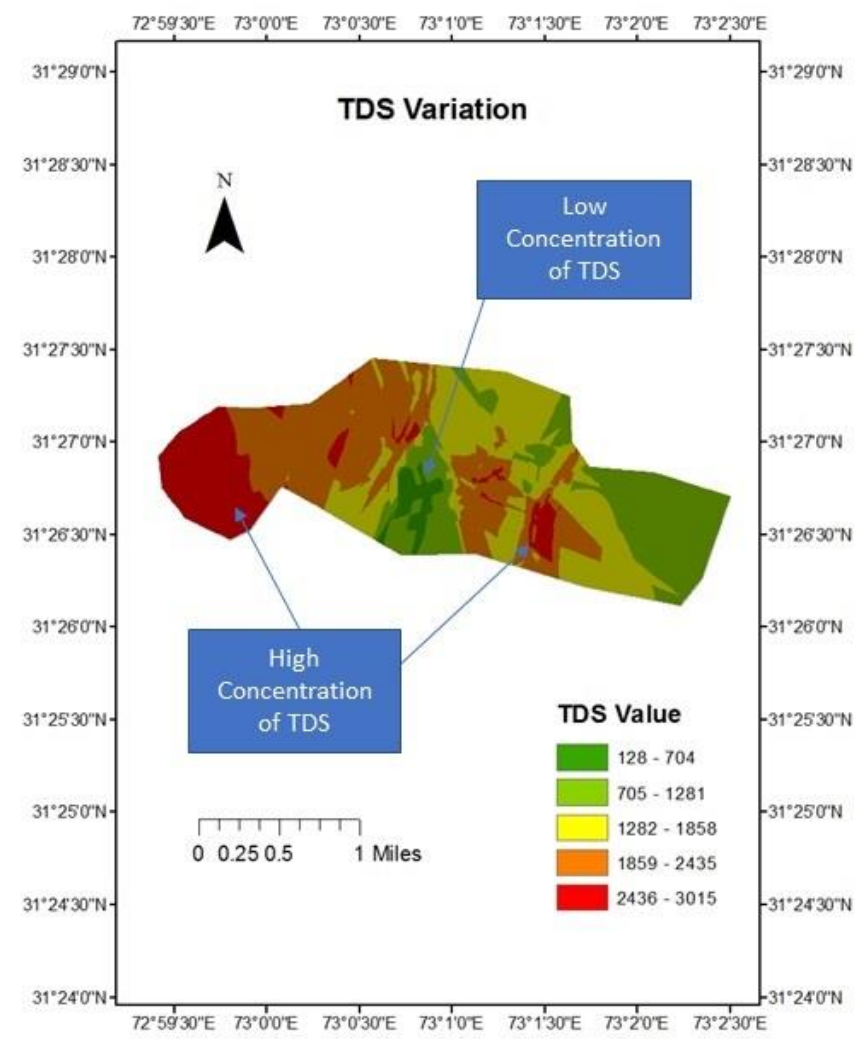

Figure 5: Variation of TDS in Different Groundwater Samples

\subsection{TSS}

Total suspended solids in water may consist of inorganic and organic particles. Suspended solid are objectionable in water as it is aesthetically displeasing and provides sites to chemical and biological agents. TSS results varied from $61 \mathrm{mg} / \mathrm{l}$ to $1455 \mathrm{mg} / \mathrm{l}$ in groundwater of study area as shown in Fig. 6.

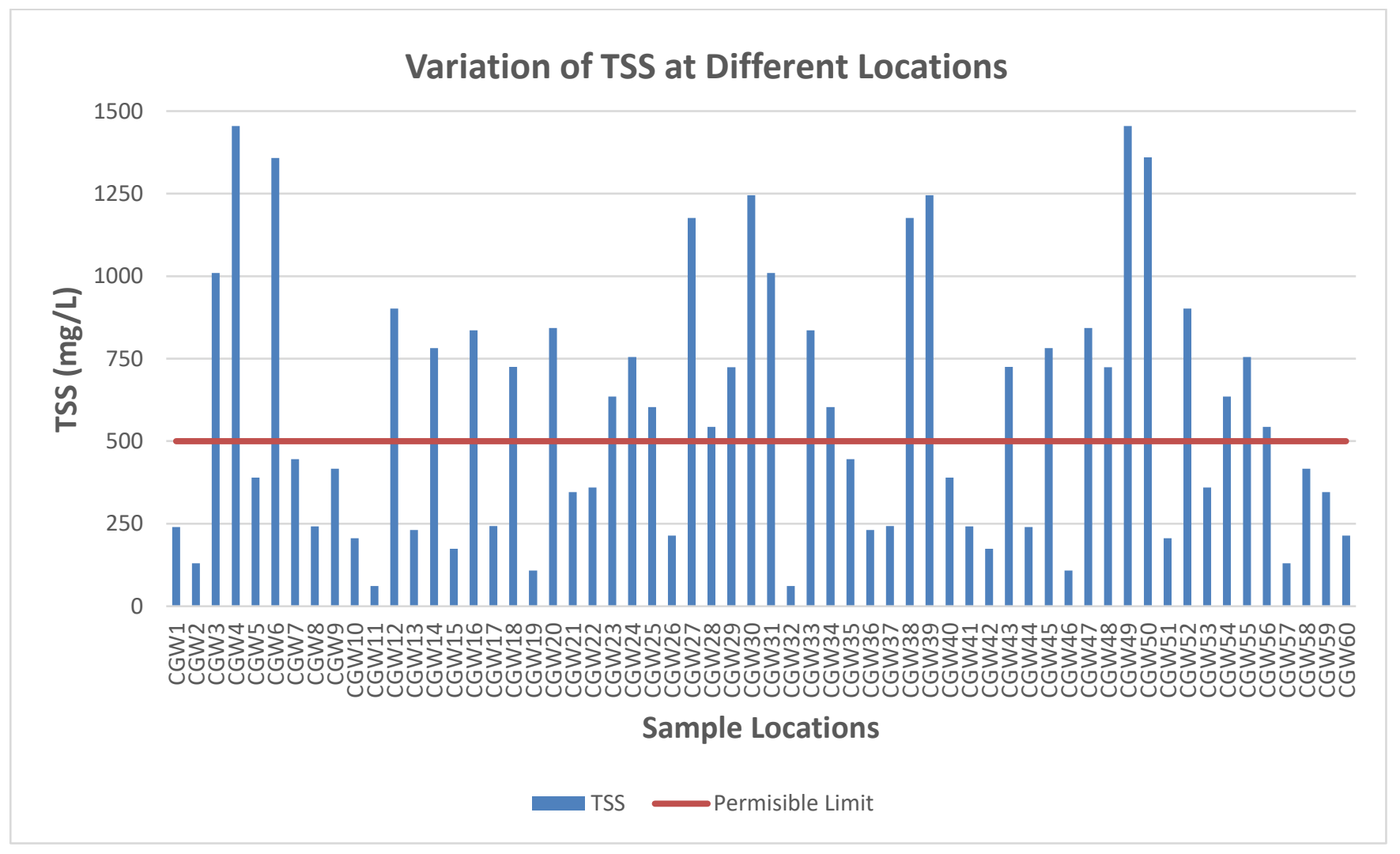

Figure 6: Variation of TSS at Different Locations 


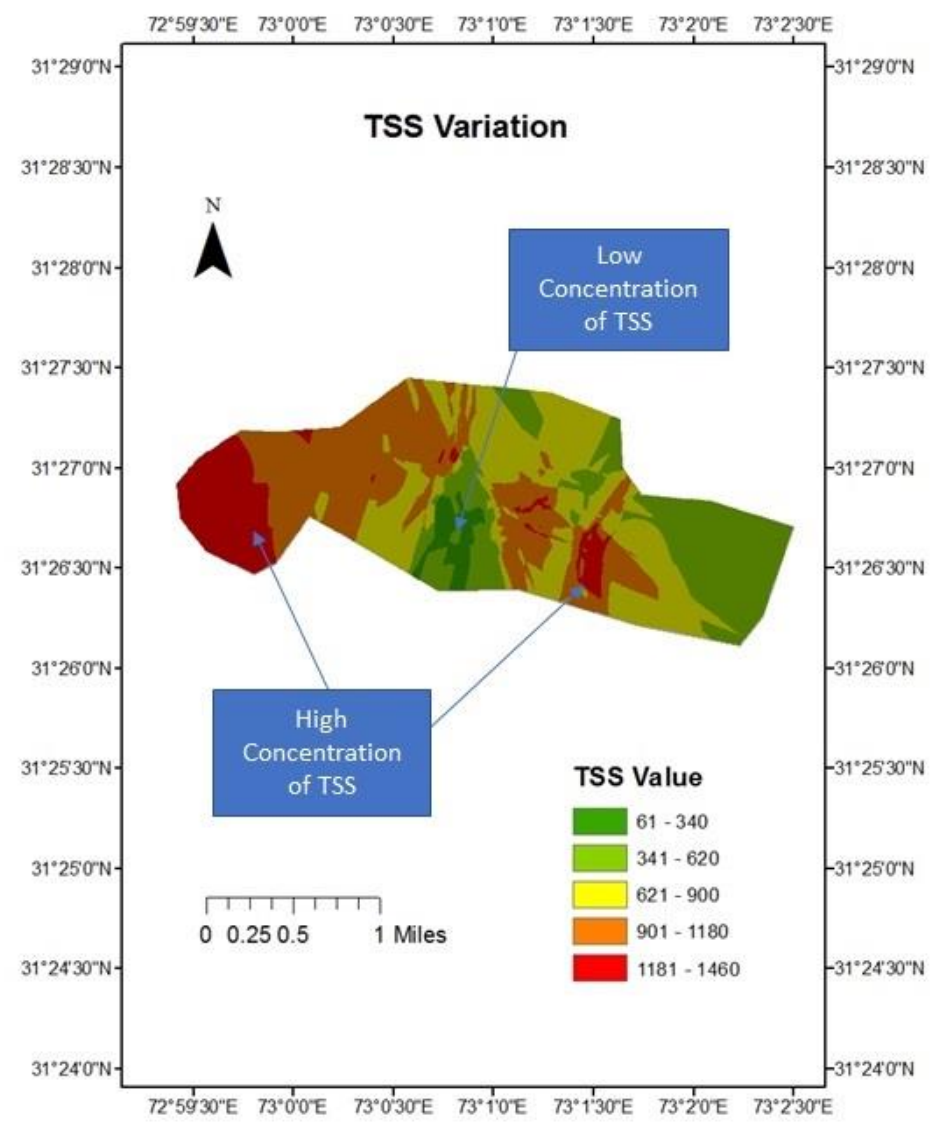

Figure 7: Variation of TSS in Different Groundwater Samples

\subsection{DO}

Dissolved Oxygen (DO) measures the quantity of oxygen that is dissolved in water. Oxygen enters into water by aeration and photosynthesis process.

DO level was measured from $7.3 \mathrm{mg} / \mathrm{l}$ to $13.5 \mathrm{mg} / \mathrm{l}$ as shown in Fig. 8.

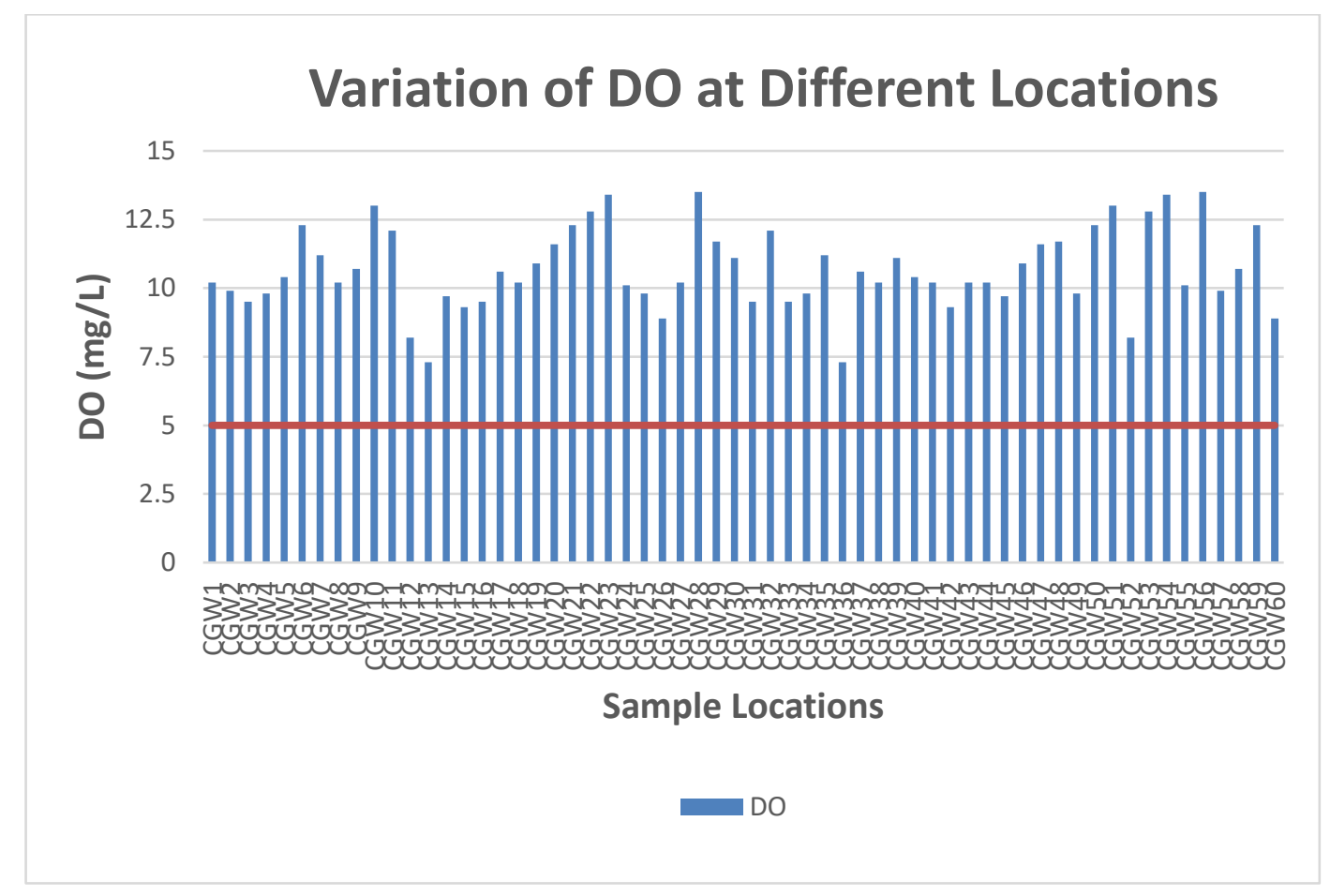

Figure 8: Variation of DO at Different Locations 


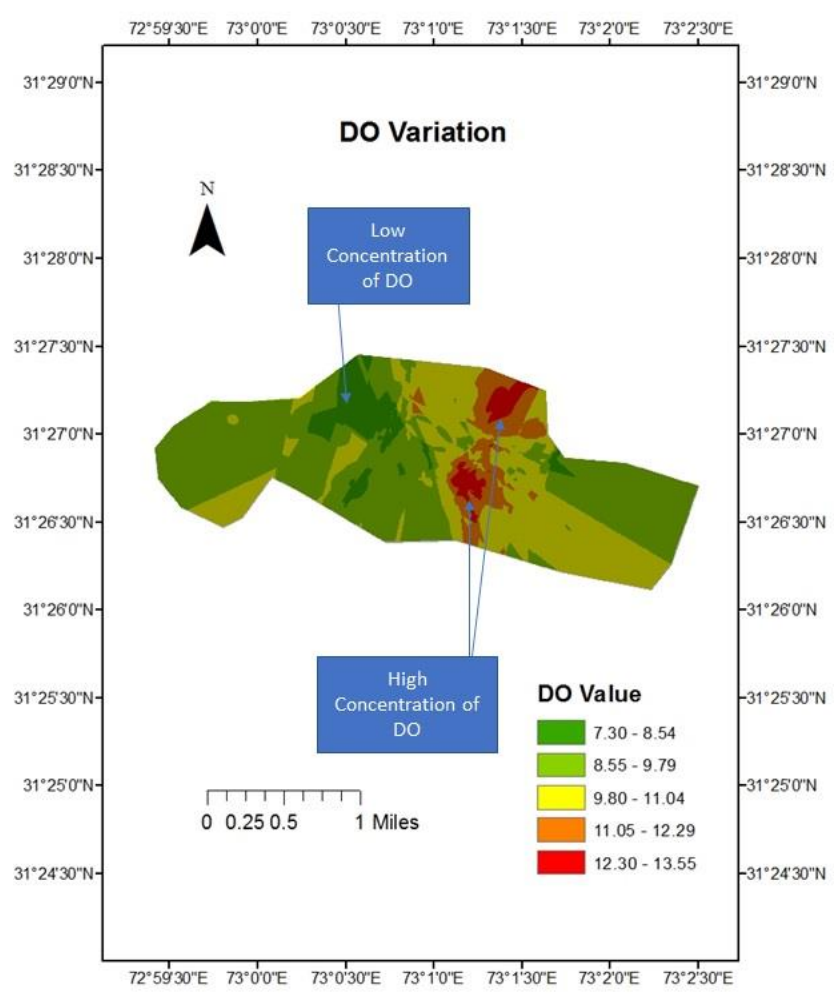

Figure 9: Variation of DO in Different Groundwater Samples

\subsection{Carbonates and Bicarbonates}

Carbonates and bicarbonates were determined to find out the Residual Sodium Carbonate (RSC) for groundwater analysis. More over Carbonates and Bicarbonates are used to find out drinking water quality standards.

The concentration of carbonates and bicarbonates varied from 19 to 384 and 65 to 1285 respectively.

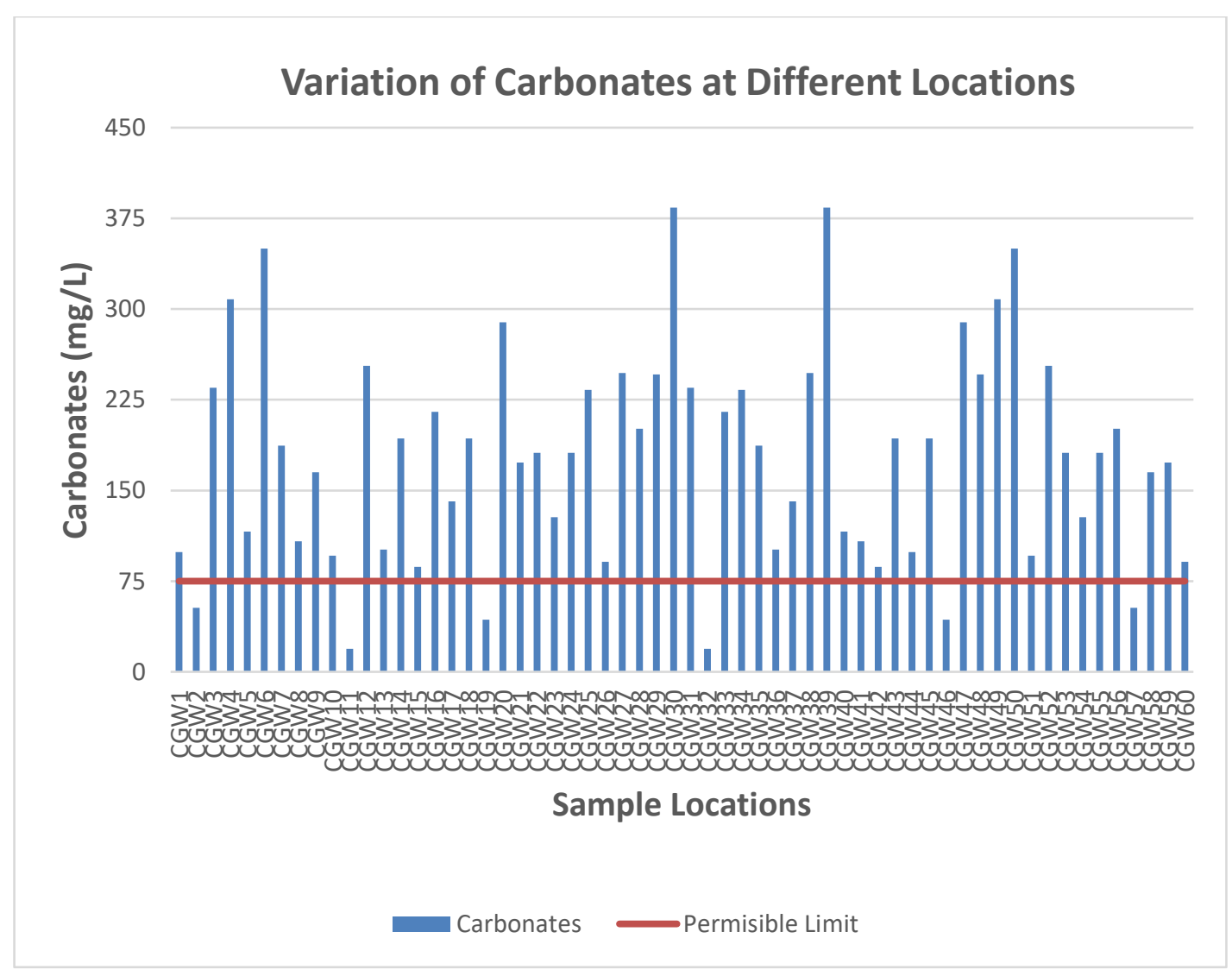

Figure 10: Variation of Carbonates at Different Locations 


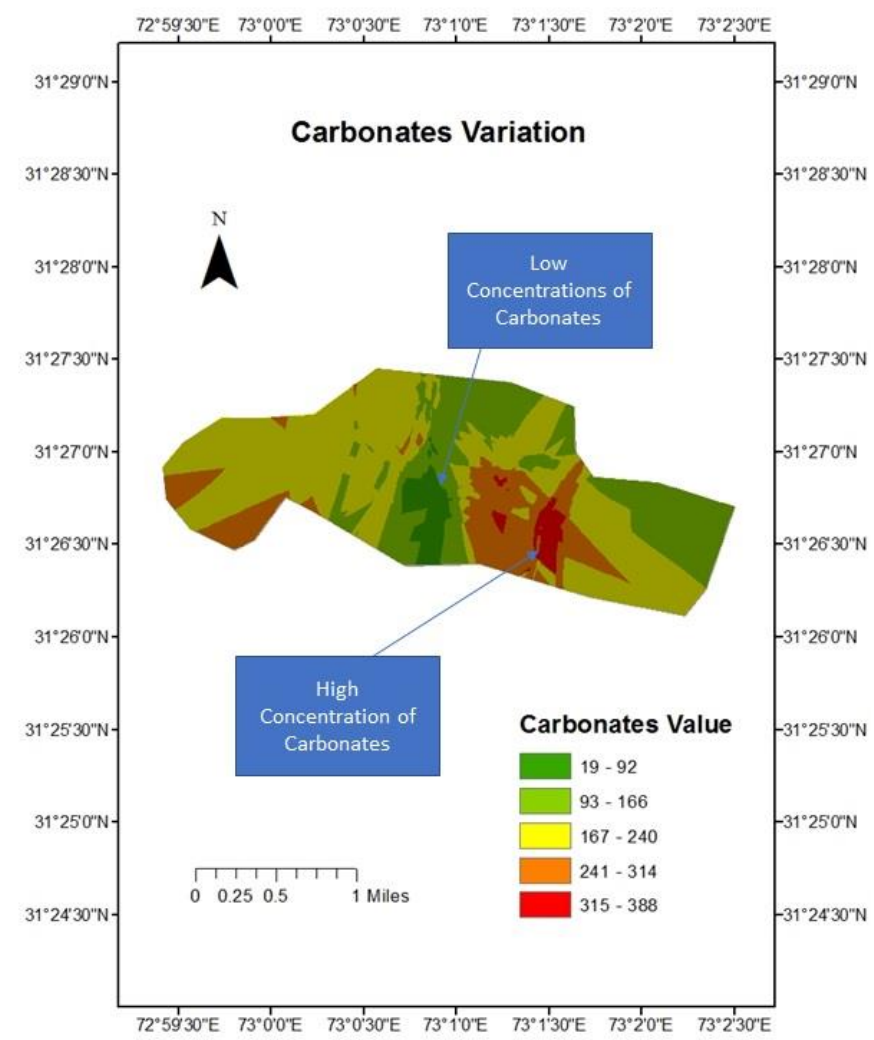

Figure 11: Variation of Carbonates in Different Groundwater Samples

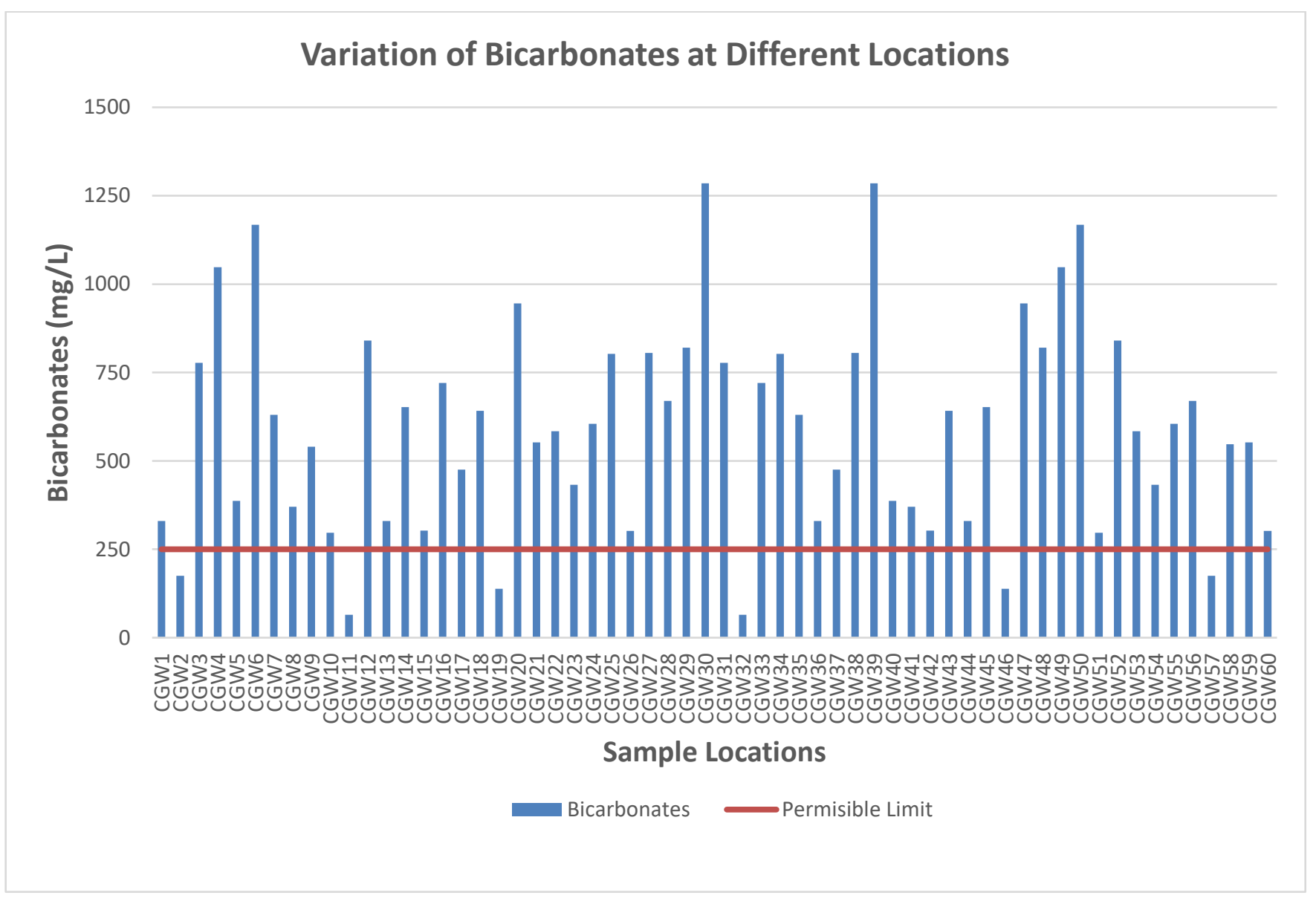

Figure 12: Variation of Bicarbonates at Different Locations 


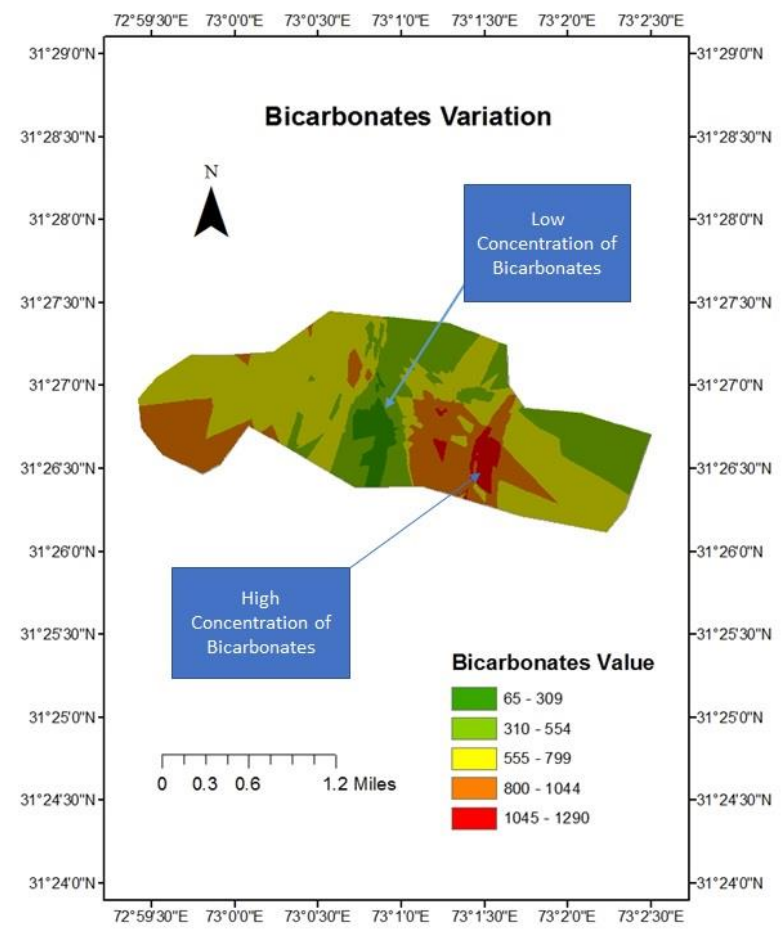

Figure 13: Variation of Bicarbonates at Different Locations

\subsection{Chloride Contents}

Some common chloride compounds found in natural water are sodium chloride $(\mathrm{NaCl})$, potassium chloride $(\mathrm{KCl})$, calcium chloride $\left(\mathrm{CaCl}_{2}\right)$ and magnesium chloride $\left(\mathrm{MgCl}_{2}\right)$. Taste thresholds for the chloride anion depend on the associated cations and the concentration ranges from 200 to $300 \mathrm{mg} / \mathrm{L}$ for sodium, potassium and calcium chloride. Based on taste threshold, WHO has prescribed $250 \mathrm{mg} / \mathrm{l}$ as the acceptable limit for chloride. The concentration of chloride in the collected samples were in the range of 32-960 mg/l (Figure 14).

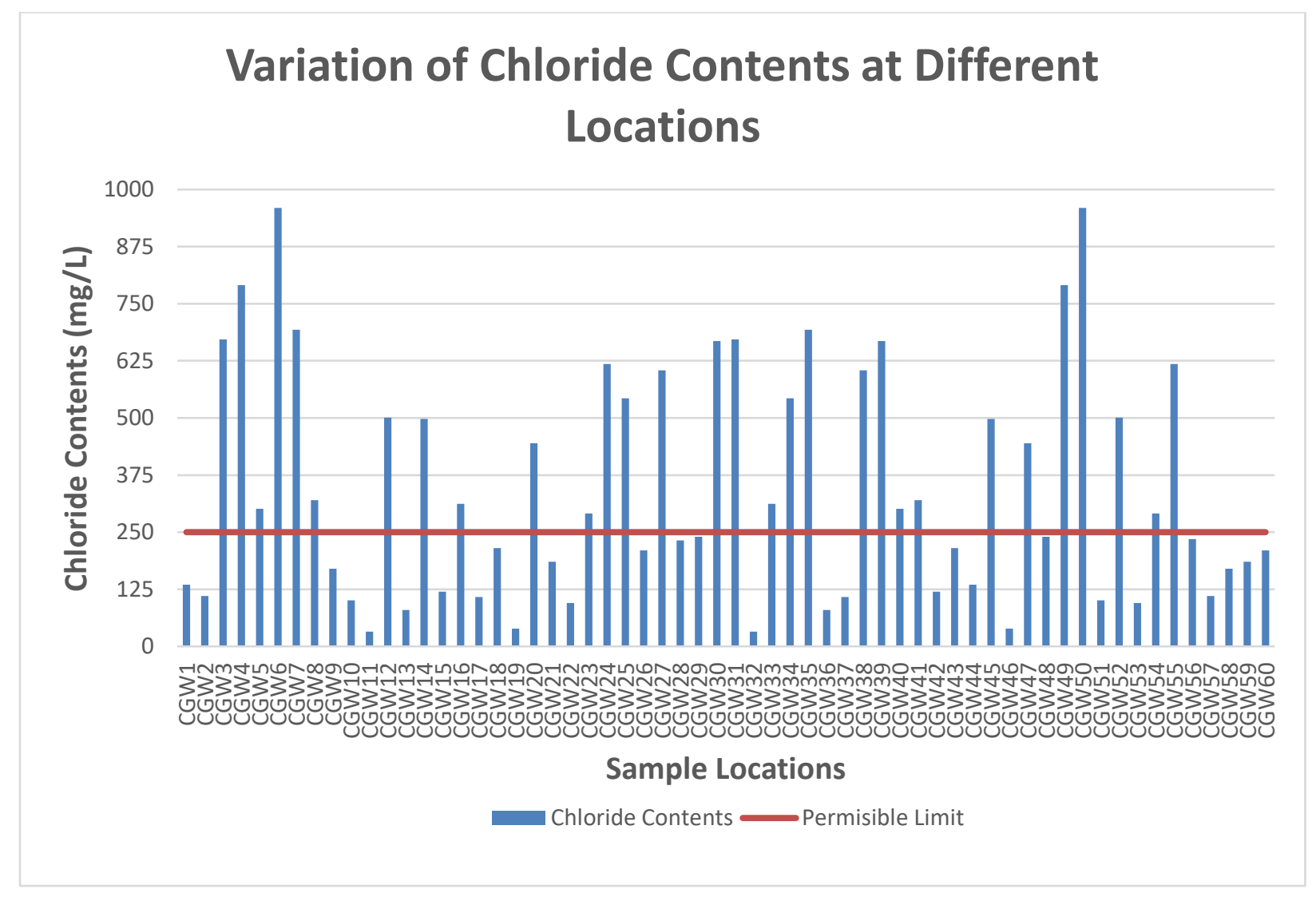

Figure 14: Variation of Chloride Contents at Different Locations 


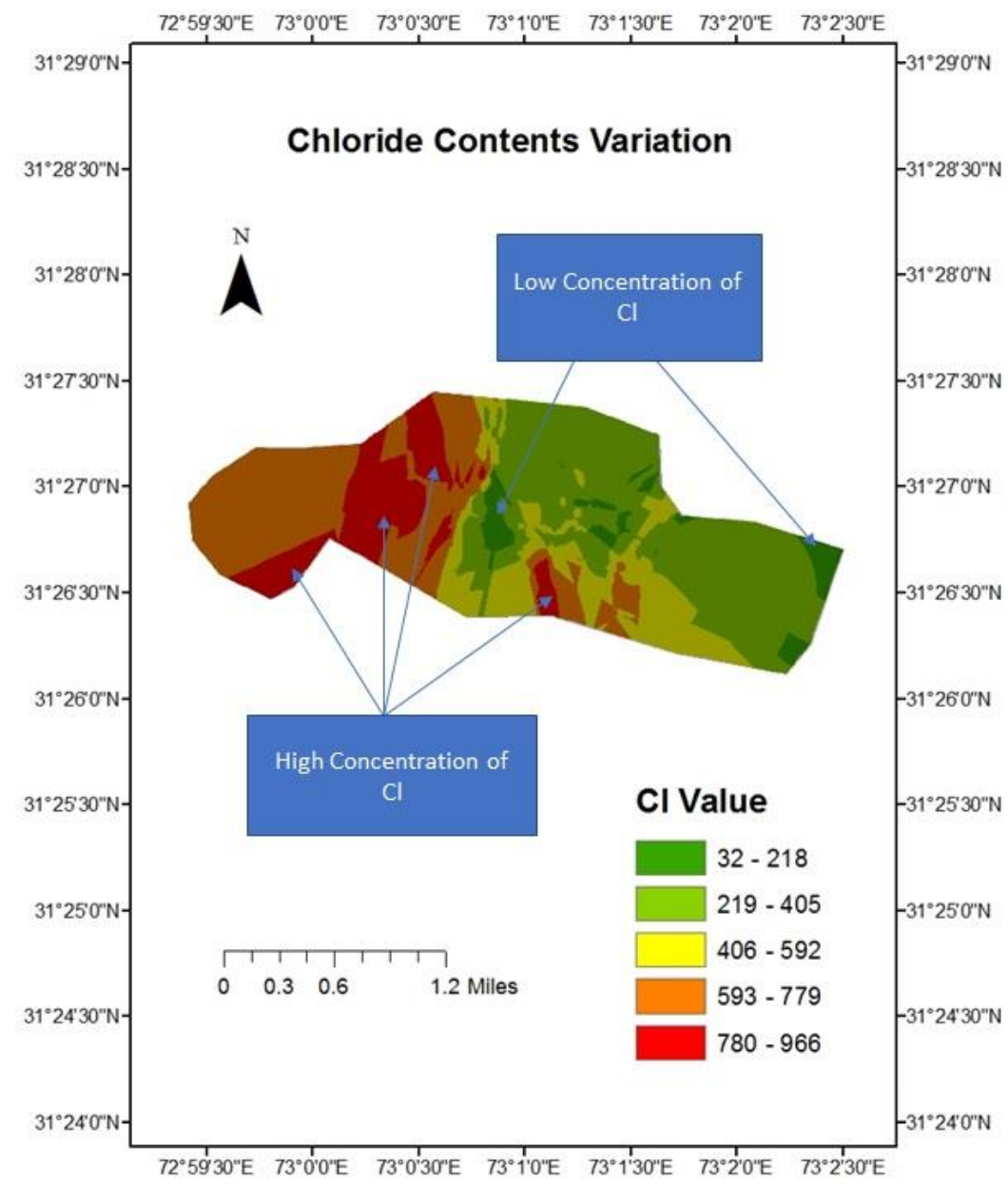

Figure 15: Variation of Chloride Contents in Different Groundwater Samples

\subsection{Arsenic}

The value of arsenic in the groundwater samples varied from 0 to 0.07 $\mathrm{mg} / \mathrm{l}$ with the average value of 0.04 . The permissible limit is $0.01 \mathrm{mg} / \mathrm{l}$ by WHO. Fig. 10 tells the whole scenario of arsenic variation in the study area.
Most of the water samples have the arsenic value above the permissible limit. The red colored area as shown in the Fig. 16 possesses the highest concentration of arsenic.

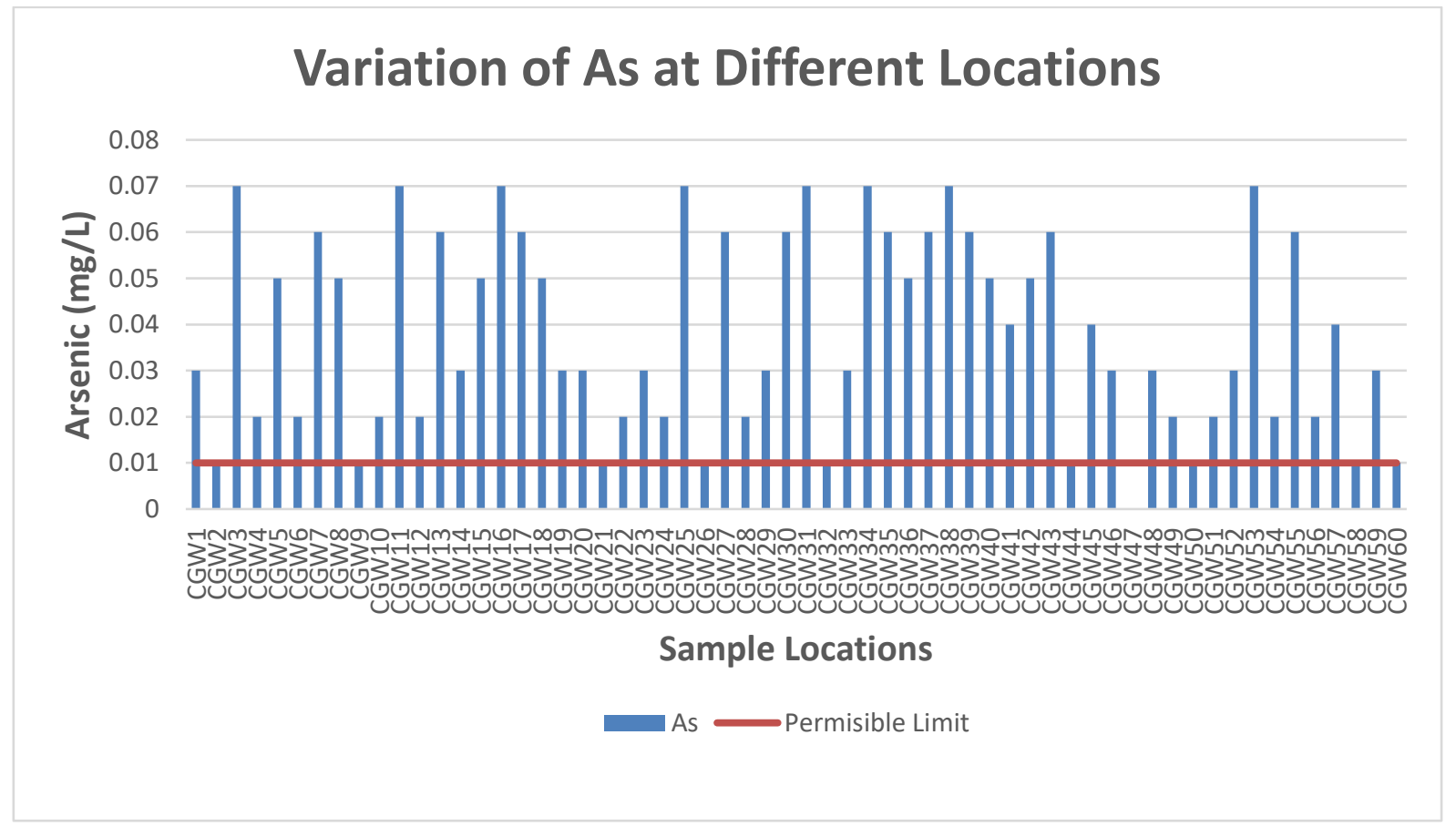

Figure 16: Variation of As at Different Locations 


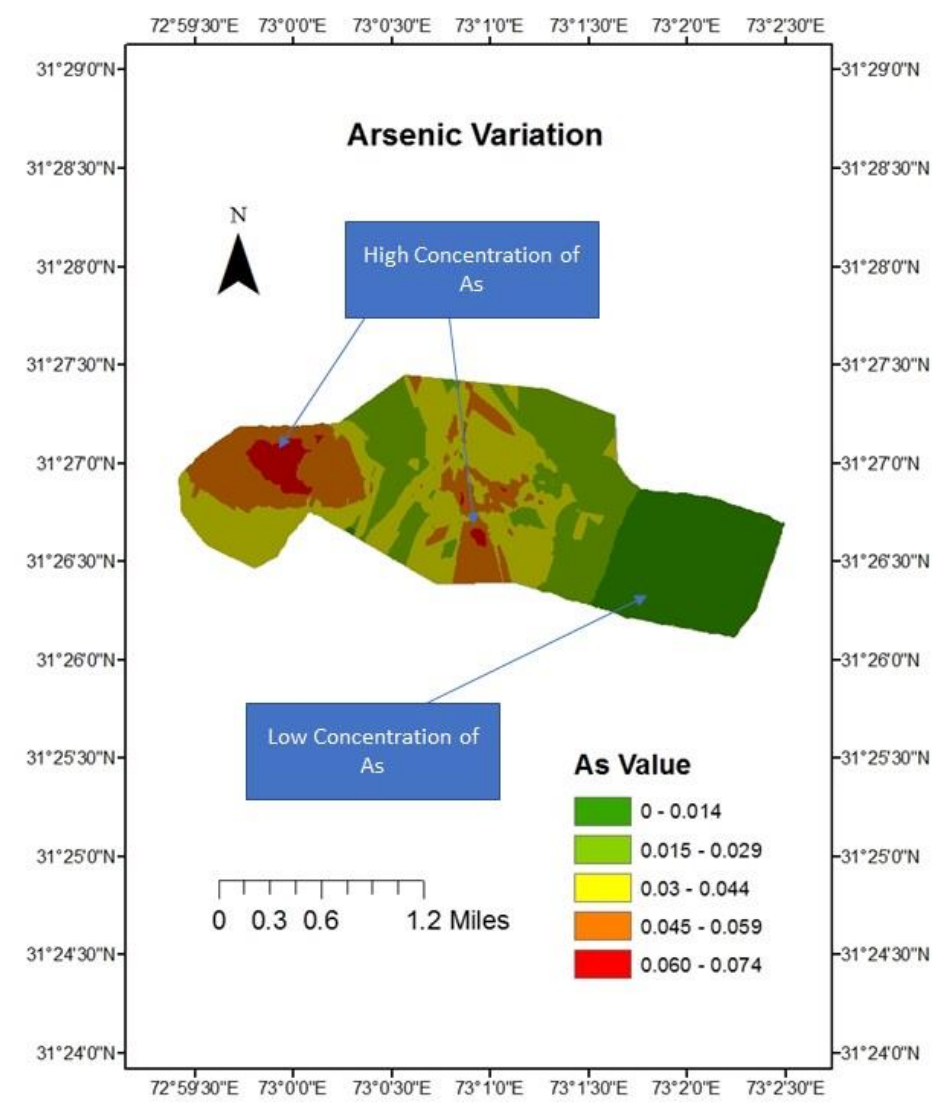

Figure 17: Variation of As in Groundwater Samples

\subsection{Lead}

The main sources of lead in water are dyes, gasoline, batteries waste, manufacturing and pipe industries. It is a serious body poison. Guideline value for lead is $0.01 \mathrm{mg} / \mathrm{l}(\mathrm{WHO}, 2011)$. Lead in groundwater samples in the study area is varied between 0.01 and $0.08 \mathrm{mg} / \mathrm{l}$. Fig. 18 indicates the value of lead in study area. The area having a high concentration of lead is indicated by yellow color on map.

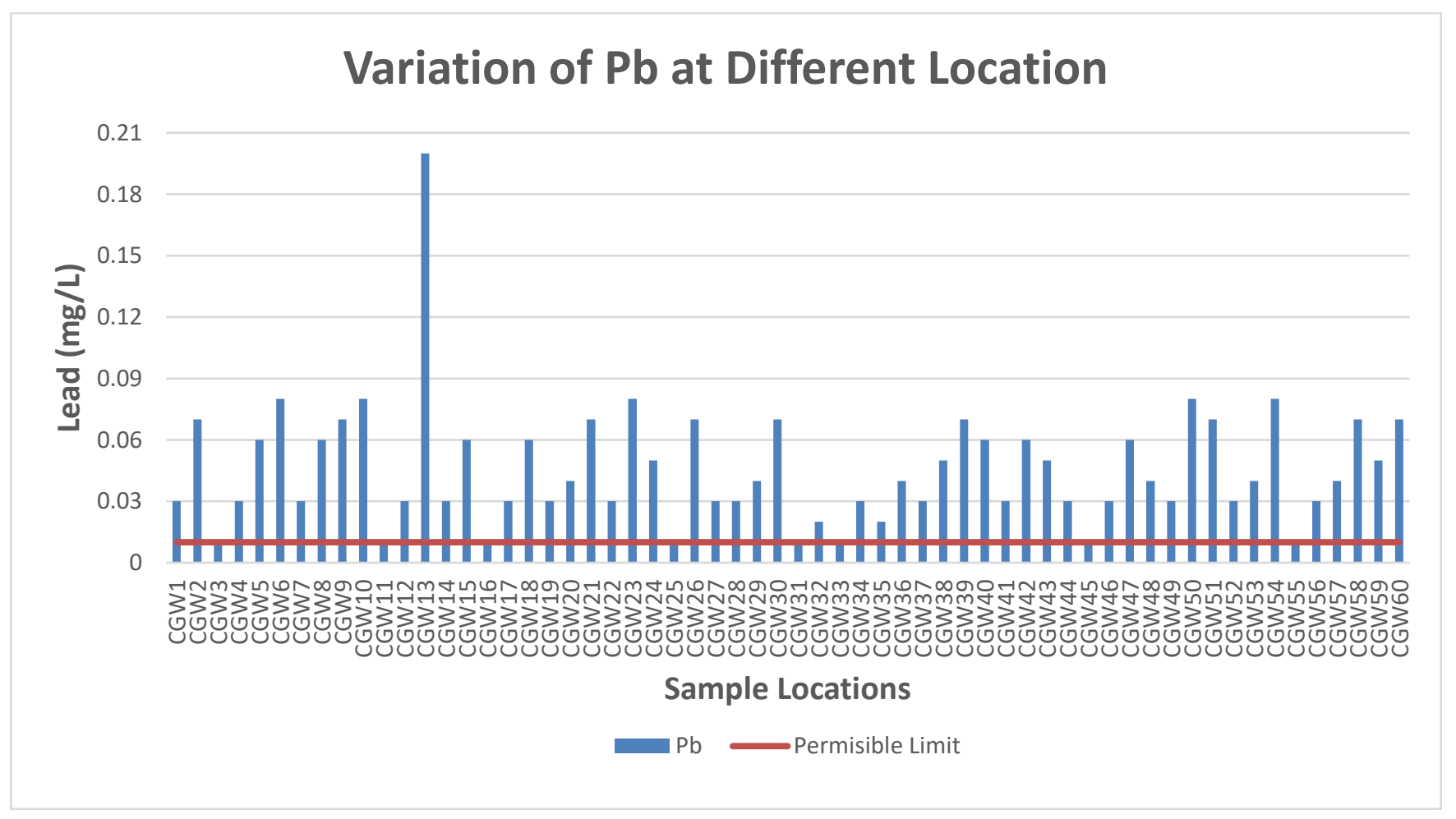

Figure 18: Variation of $\mathrm{Pb}$ at Different Locations 


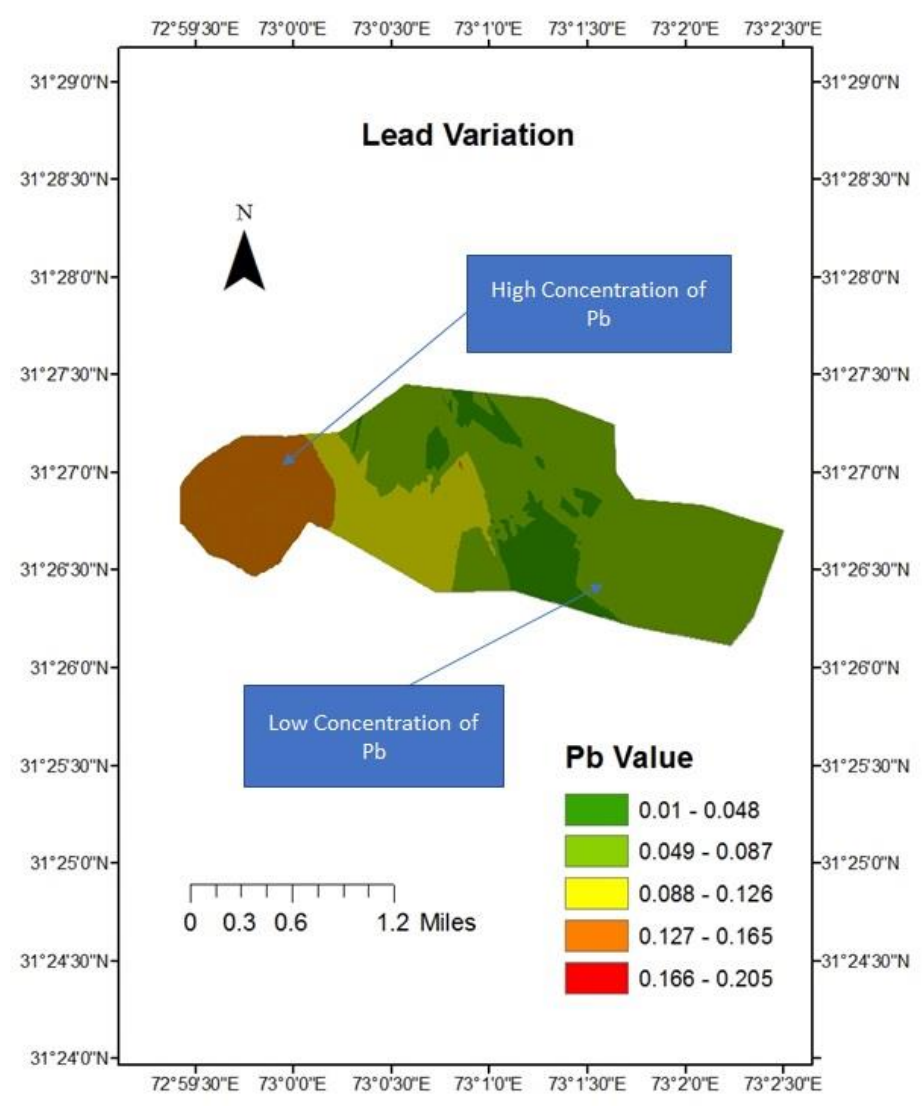

Figure 19: Variation of $\mathrm{Pb}$ in Groundwater Samples

\subsection{Cadmium}

The value cadmium in groundwater samples of Chokera varied between 0 and $0.08 \mathrm{mg} / \mathrm{l}$. The average value of cadmium variation was recorded as 0.04. Permissible limit for cadmium is $0.01 \mathrm{mg} / \mathrm{l}$ [11]. Figure 20 shows the spatial variability of cadmium in groundwater samples of study area.

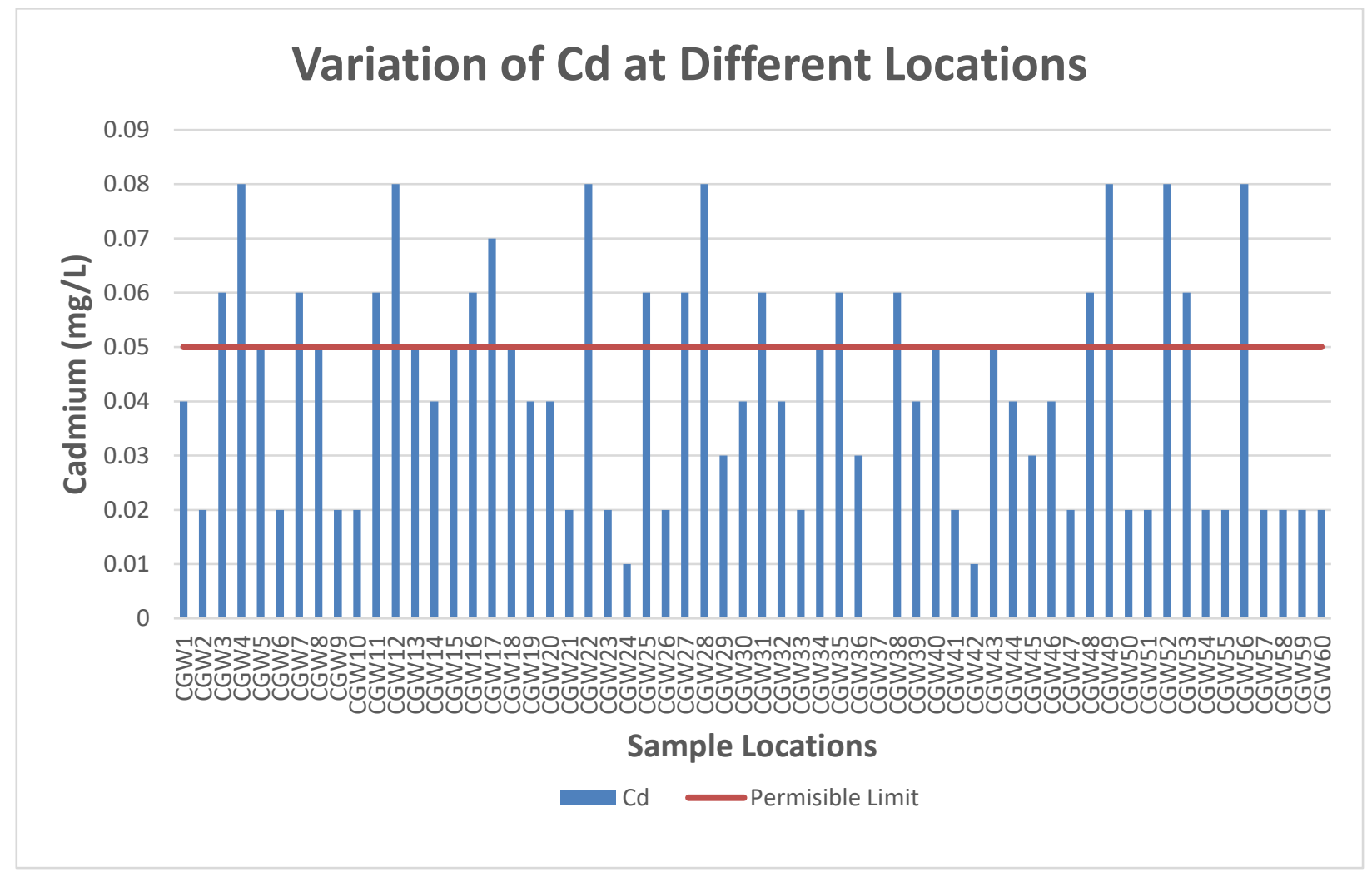

Figure 20: Variation of Cd at Different Locations 


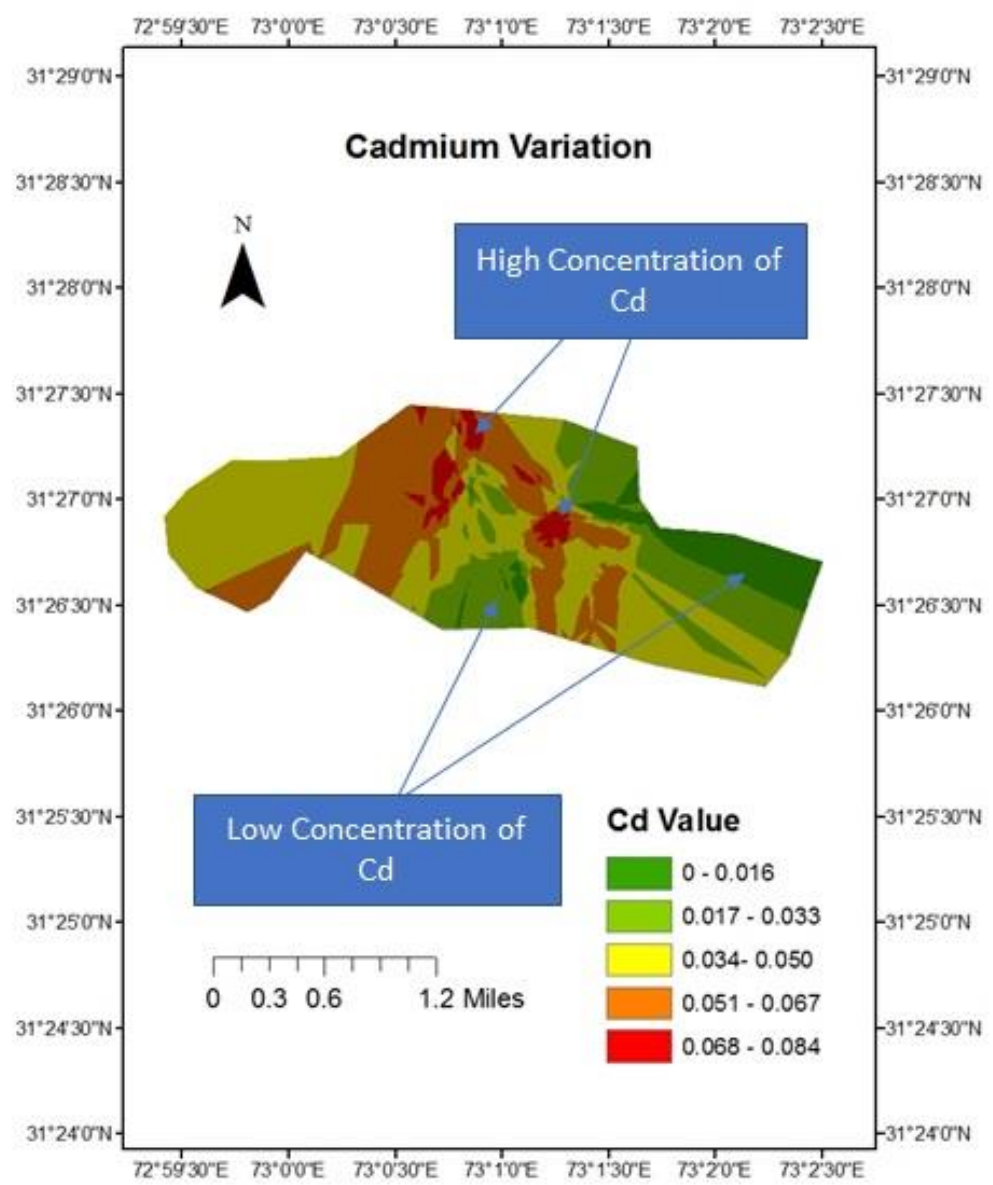

Figure 21: Variation of Cd in Groundwater Samples

\subsection{Copper}

The value of copper in groundwater samples of Chokera varied between 0 and $0.08 \mathrm{mg} / \mathrm{l}$. The average value of cadmium variation was recorded as 0.04 . Permissible limit for copper is $0.05 \mathrm{mg} / \mathrm{l}$. Figure 22 shows the spatial variability of copper in groundwater samples of study area.

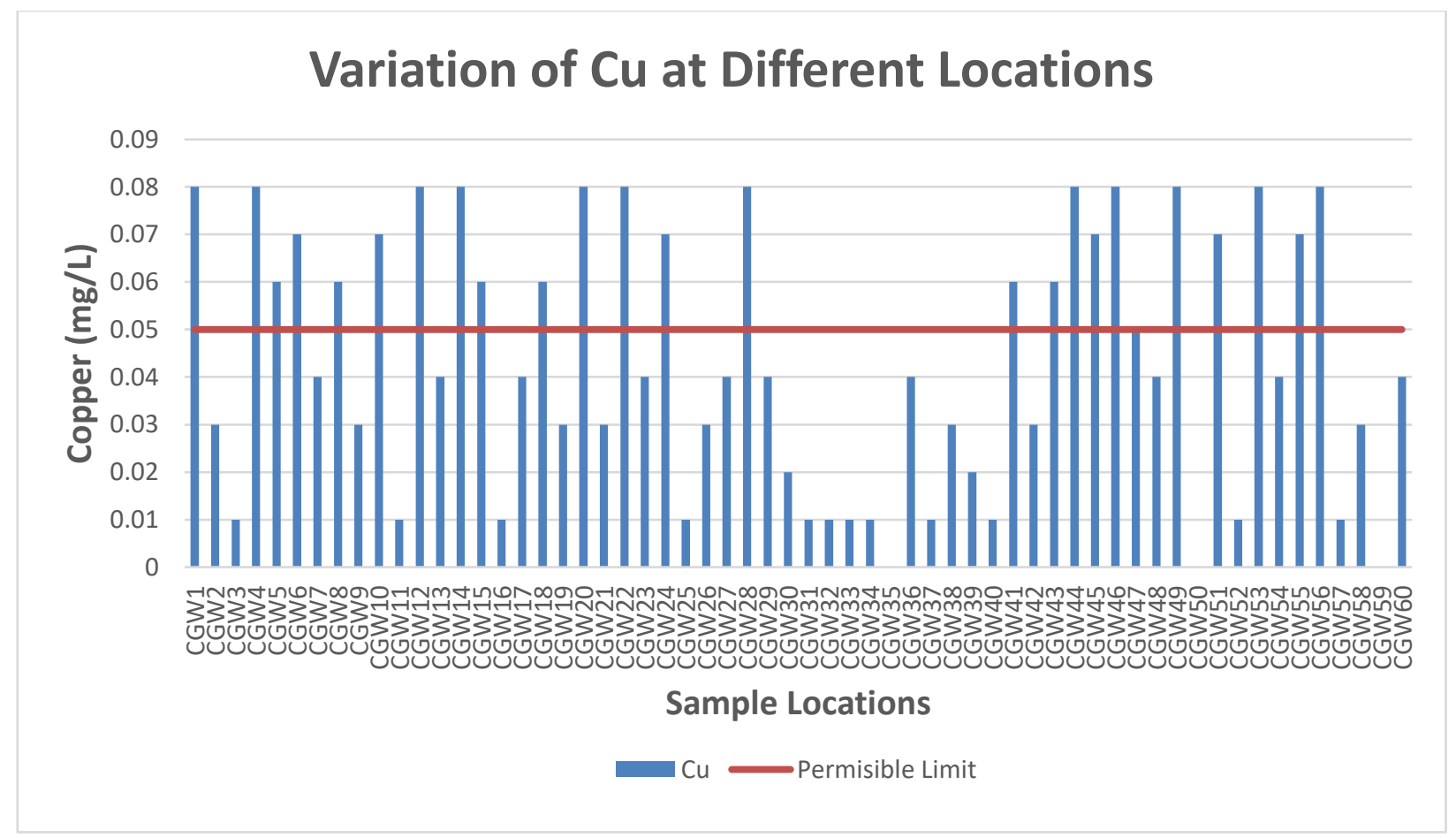

Figure 22: Variation of $\mathrm{Cu}$ at Different Locations 


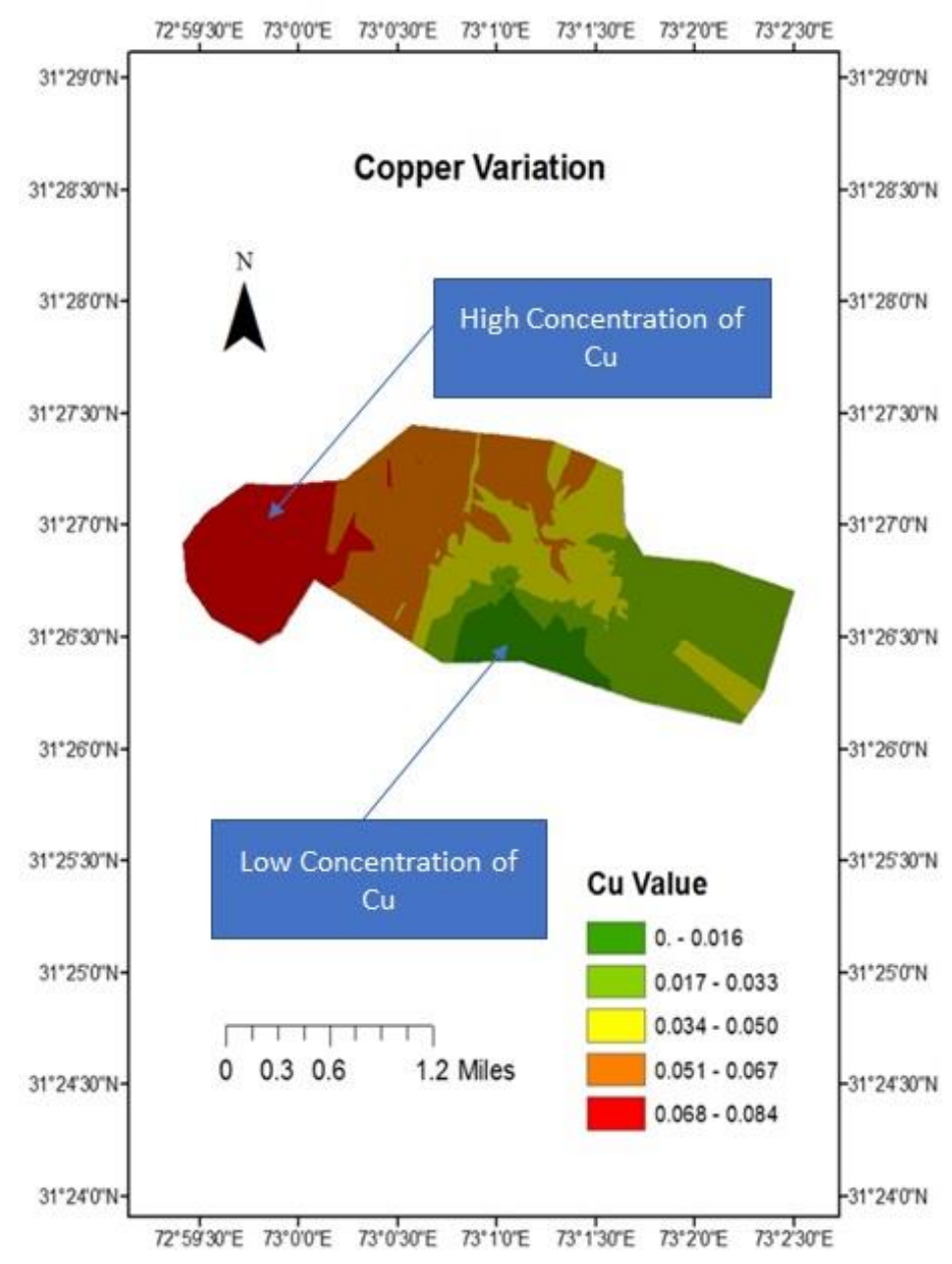

Figure 23: Variation of $\mathrm{Cu}$ in Groundwater Samples

\subsection{Chromium}

The chromium concentration of groundwater samples obtained from Chokera ranged from 0.01 to $0.08 \mathrm{mg} / \mathrm{l}$. The average value of all the samples was 0.04 . Figure 24 shows the spatial variability of chromium in the groundwater samples. The sources of chromium in water includes; mining, garbage disposal, soaps and detergents, industrial effluents and agricultural activities [12]. Long term exposure to chromium posed threat to human life and can cause kidney, liver circulatory and nerve tissue damages.

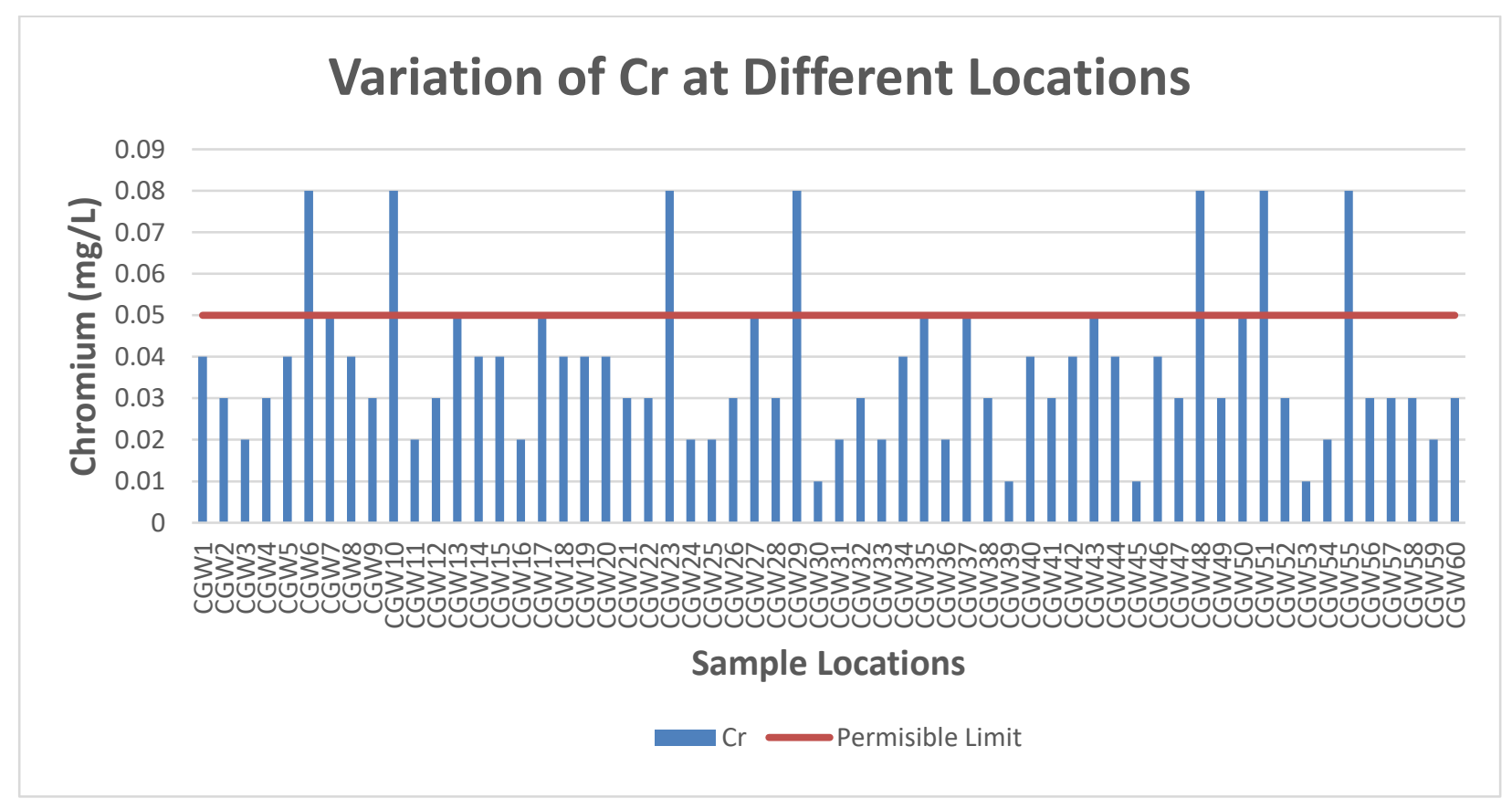

Figure 24: Variation of Cr at Different Locations 


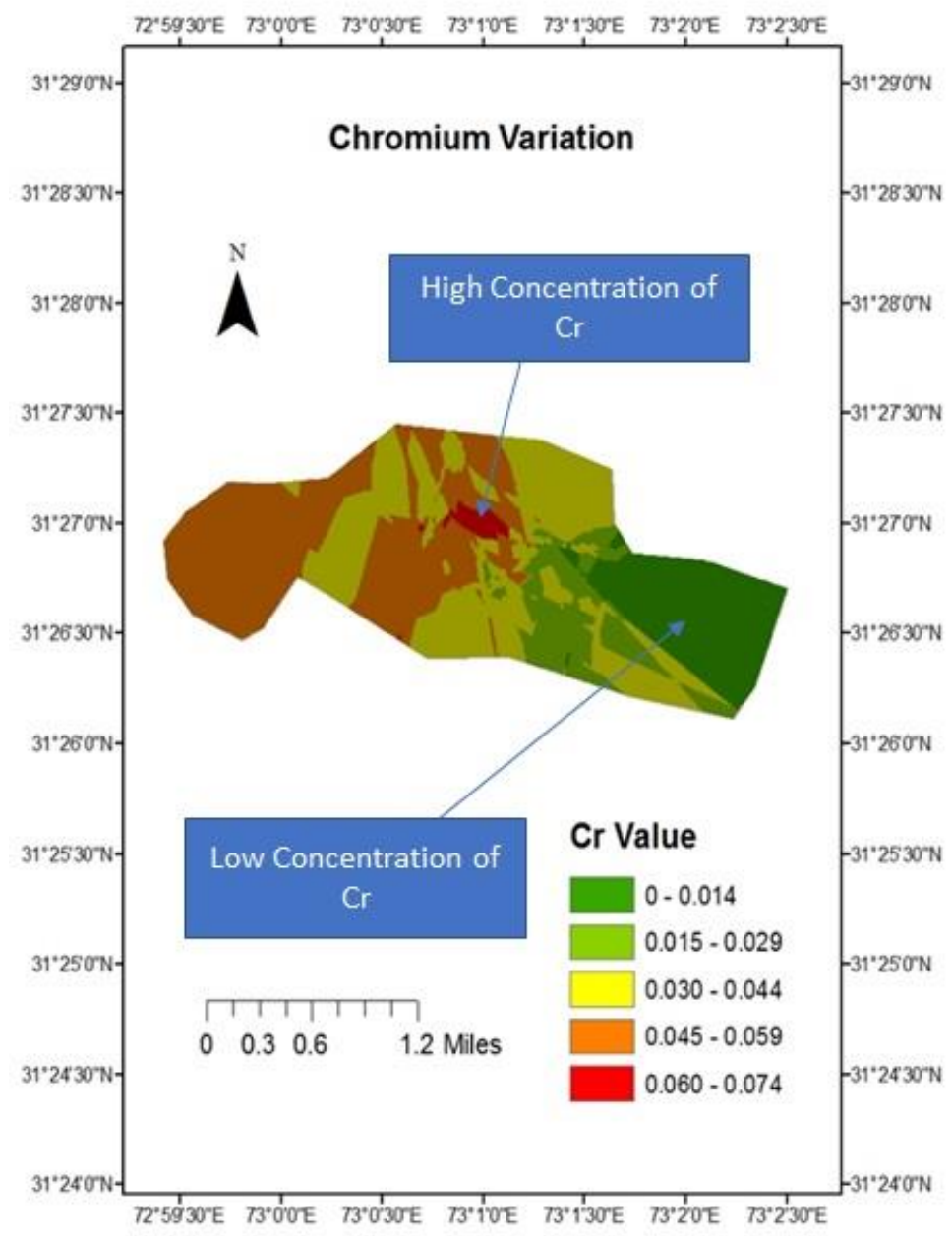

Figure 25: Variation of $\mathrm{Cr}$ in Groundwater Samples

\subsection{Zinc}

Zinc values for groundwater were ranging between 0.01 to $0.07 \mathrm{mg} / \mathrm{l}$. GIS map shows the concentration of Zinc (Zn) in groundwater as shown in Fig. 26. The GIS study explores that Zn level was found high in the groundwater samples at the western side.

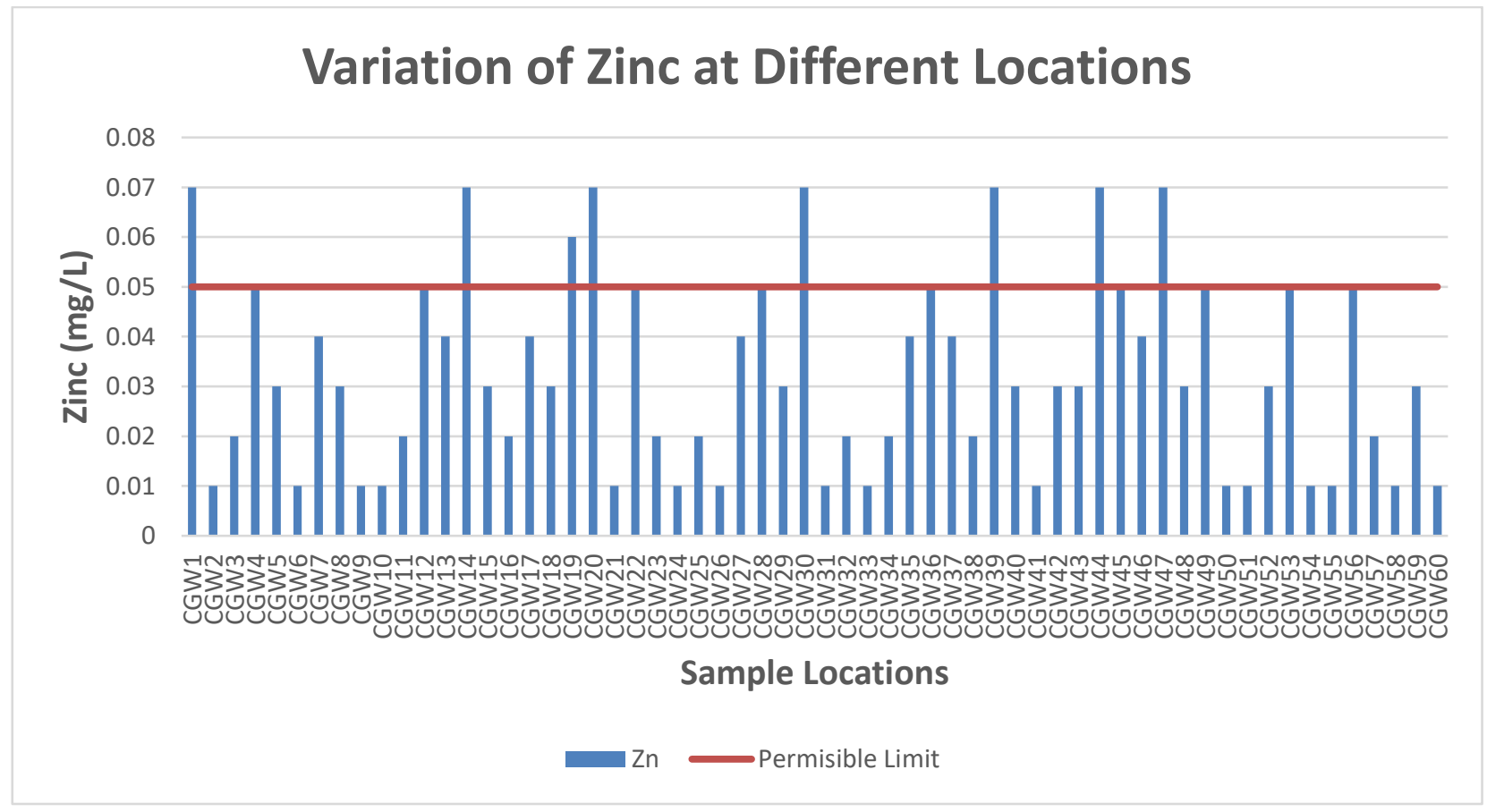

Figure 26: Variation of Zn at Different Locations 


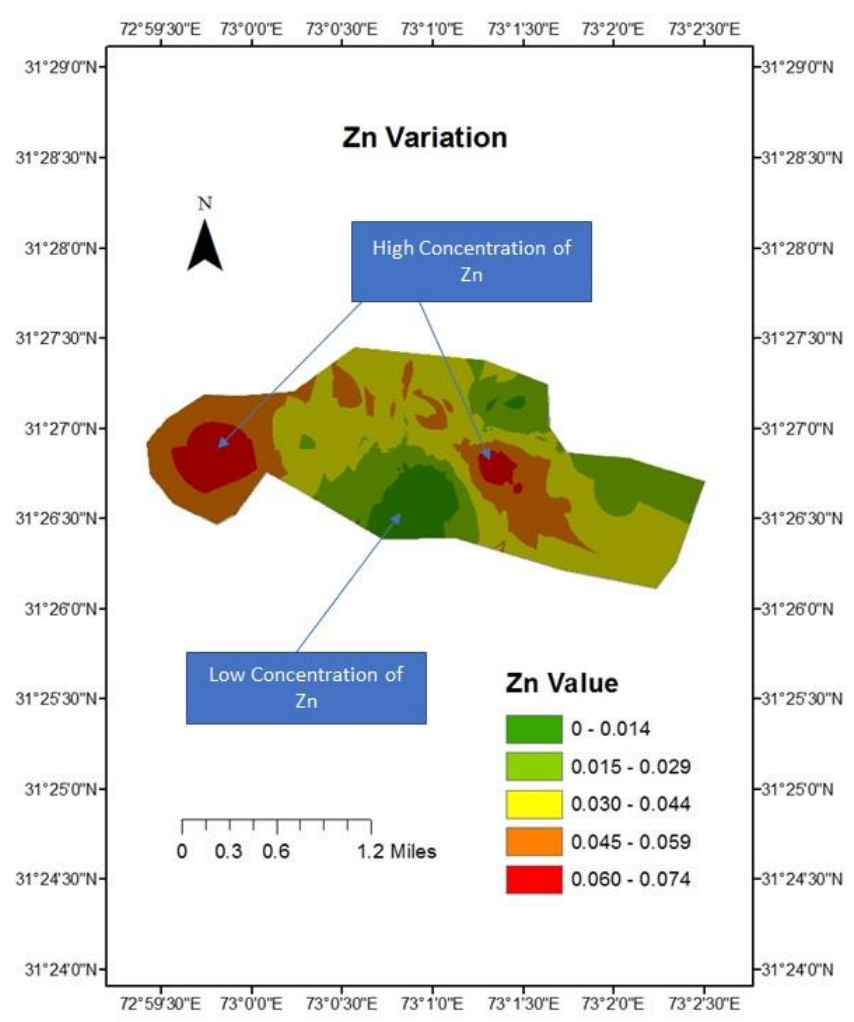

Figure 27: Variation of Zn in Groundwater Samples

\section{$3.13 \mathrm{WQI}$}

In this study, the computed WQI value ranges from 73 to 272 as shown in Table 3 . It can be categorized into poor and very poor water.

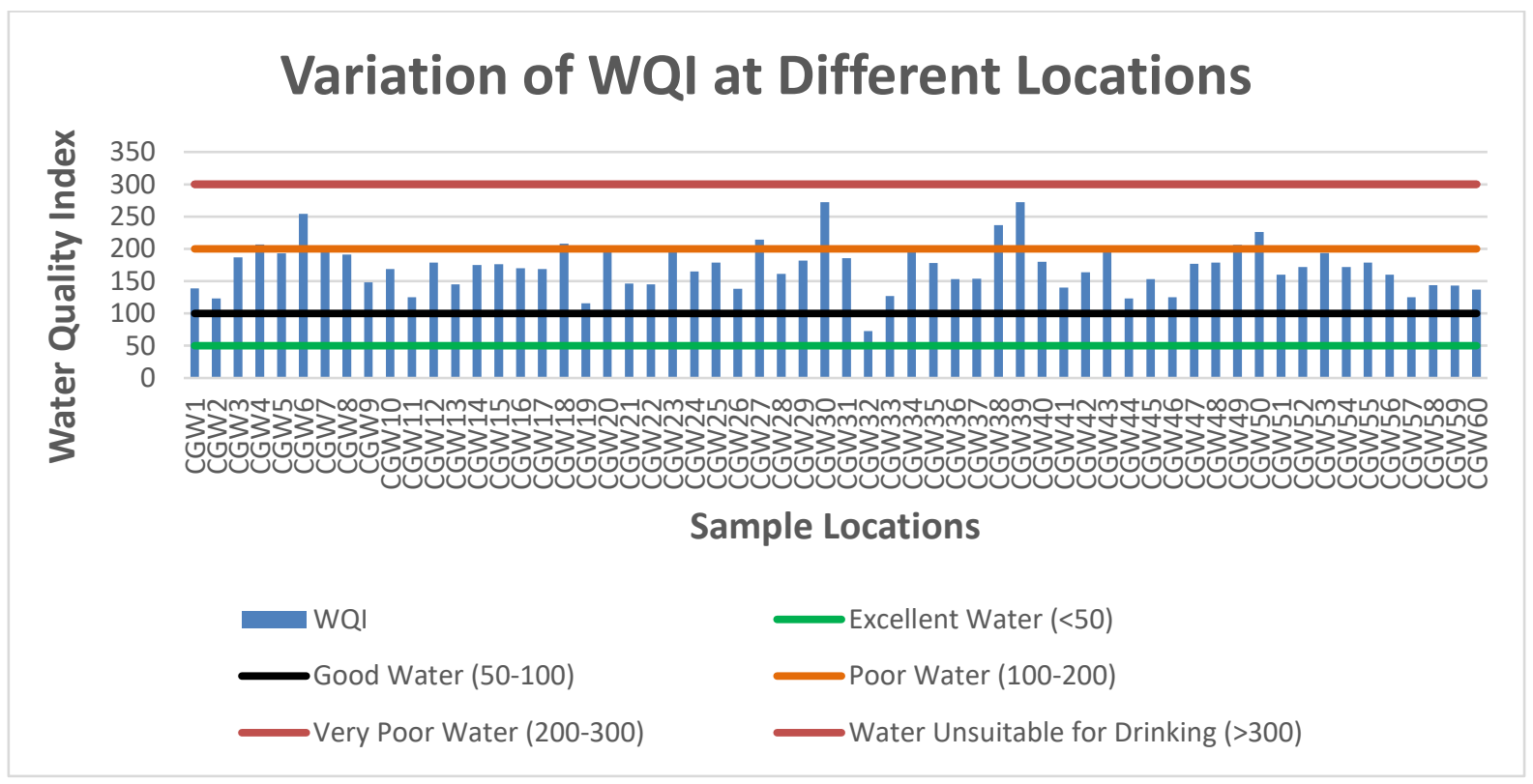

Figure 28: Variation of WQI at Different Locations

Table 3: Details of Water Quality and Index Rate of Analysed Samples

\begin{tabular}{|c|c|c|c|c|c|c|c|}
\hline Sr. No. & Sample Code & Index Rate & Water Quality & Sr. No. & Sample Code & Index Rate & Water Quality \\
\hline 1 & CGW1 & 139 & Poor Water & 31 & CGW31 & 185.7 & Poor Water \\
\hline 2 & GGW2 & 123 & Poor Water & 32 & CGW32 & 73 & Good Water \\
\hline 3 & CGW3 & 187 & Poor Water & 33 & CGW33 & 127 & Poor Water \\
\hline 4 & CGW4 & 207 & Very Poor Water & 34 & CGW34 & 205 & Very Poor Water \\
\hline 5 & GGW5 & 193 & Poor Water & 35 & CGW35 & 178 & Poor Water \\
\hline 6 & CGW6 & 254 & Very Poor Water & 36 & CGW36 & 153 & Poor Water \\
\hline 7 & CGW7 & 200 & Very Poor Water & 37 & CGW37 & 154 & Poor Water \\
\hline 8 & CGW8 & 191 & Poor Water & 38 & CGW38 & 237 & Very Poor Water \\
\hline
\end{tabular}




\begin{tabular}{|c|c|c|c|c|c|c|c|}
\hline 9 & CGW9 & 148 & Poor Water & 39 & CGW39 & 272 & Very Poor Water \\
\hline 10 & CGW10 & 169 & Poor Water & 40 & CGW40 & 180 & Poor Water \\
\hline 11 & CGW11 & 125 & Poor Water & 41 & CGW41 & 140 & Poor Water \\
\hline 12 & CGW12 & 179 & Poor Water & 42 & CGW42 & 164 & Poor Water \\
\hline 13 & CGW13 & 145 & Poor Water & 43 & CGW43 & 201 & Very Poor Water \\
\hline 14 & CGW14 & 175 & Poor Water & 44 & CGW44 & 123 & Poor Water \\
\hline 15 & CGW15 & 176 & Poor Water & 45 & CGW45 & 153 & Poor Water \\
\hline 16 & CGW16 & 170 & Poor Water & 46 & CGW46 & 125 & Poor Water \\
\hline 17 & CGW17 & 169 & Poor Water & 47 & CGW47 & 177 & Poor Water \\
\hline 18 & CGW18 & 208 & Very Poor Water & 48 & CGW48 & 179 & Poor Water \\
\hline 19 & CGW19 & 116 & Poor Water & 49 & CGW49 & 206 & Very Poor Water \\
\hline 20 & CGW20 & 197 & Poor Water & 50 & CGW50 & 226 & Very Poor Water \\
\hline 21 & CGW21 & 146 & Poor Water & 51 & CGW51 & 160 & Poor Water \\
\hline 22 & CGW22 & 145 & Poor Water & 52 & CGW52 & 172 & Poor Water \\
\hline 23 & CGW23 & 195 & Poor Water & 53 & CGW53 & 194 & Poor Water \\
\hline 24 & CGW24 & 165 & Poor Water & 54 & CGW54 & 172 & Poor Water \\
\hline 25 & CGW25 & 179 & Poor Water & 55 & CGW55 & 179 & Poor Water \\
\hline 26 & CGW26 & 138 & Poor Water & 56 & CGW56 & 160 & Poor Water \\
\hline 27 & CGW27 & 214 & Very Poor Water & 57 & CGW57 & 125 & Poor Water \\
\hline 28 & CGW28 & 161 & Very Poor Water & 58 & CGW58 & 144 & Poor Water \\
\hline 29 & CGW29 & 182 & Poor Water & 59 & CGW59 & 143 & Poor Water \\
\hline 30 & CGW30 & 272 & Very Poor Water & 60 & CGW60 & 137 & Poor Water \\
\hline
\end{tabular}

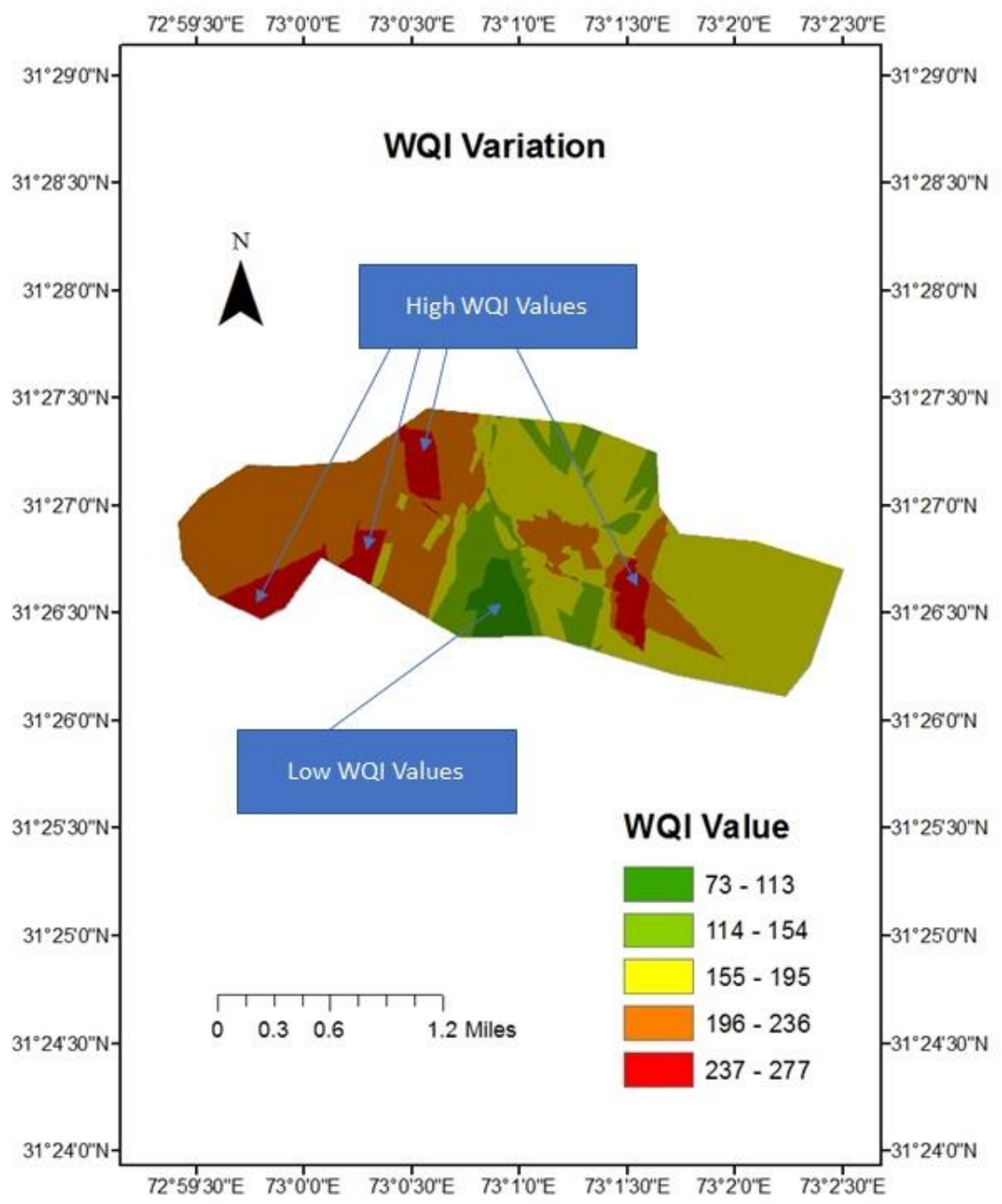

Figure 29: Variation of WQI in Different Groundwater Samples

\section{CONCLUSION}

The ground water which were taken from the various places from Chokera area were analyzed and the analysis reports shows that the water quality parameters like $\mathrm{pH}$ and Total Dissolved Solids of few samples lies within the permissible limit prescribed by WHO, but many other parameters were reported beyond the permissible level, which have an impact on the water to use for drinking purpose. The analysis of experimental investigation on quality of groundwater using fourteen physico-chemical parameters of the study area indicate that the water quality was poor and very poor for drinking purpose. In this study, the computed WQI values ranges from 73 to 272 . The overall view of the Water Quality Index of the present study zone had a higher WQI value indicating the deteriorated water quality. 


\section{ACKNOWLEDGEMENT}

The authors of this paper are thankful to University of Agriculture, Faisalabad (UAF) and Water and Sanitation Agency (WASA), Faisalabad for supporting this research work by funding and providing lab facilities.

\section{REFERENCES}

[1] Nasir, A., Nasir, M.S., Shauket, I., Anwar, S., Ayub, I. 2016. Impact of samanduri drain on water resources of Faisalabad. Advances in Environmental Biology, 10(1), 155-160.

[2] Ensik, J. 2003. National Water Survey. International Water Management Institute.

[3] Khurshid, A., Ali, W. 1999. Evaluation of water quality of rivers in Pakistan. In National Workshop on Water resources Achievements and Issues in 20th Century and Challenges for the Next Millinium. Proceedings of the Pakistan Council of Research in Water Resources, 406-416.

[4] Ambiga, K., Anna, D.R. 2013. Use of geographical information system and water quality index to assess groundwater quality in and around Ranipet area, Vellore district, Tamilnadu. International Journal of Advanced Engineering Research and Studies, 2249-8974.

[5] Girija, T.R., Mahanta, C., Chandramouli, V. 2007. Water quality assessment of an untreated effluent impacted urban stream: The Bharalu tributary of the Brahmaputra River, India. Environmental Monitoring and
Assessment, 130, 221-236. DOI: http://dx.doi.org/10.1007/s10661-0069391-6

[6] Ashraf, M. 2015. Importance of Water in the Light of Quran and Sunnah and Ways of its Saving. Pakistan Council of Research in Water Resources (PCRWR) Islamabad, 37.

[7] Horton, R.K. 1965. An index number system for rating water quality. Journal of Water Pollution Control Federation, 37, 300-305.

[8] Brown, R.M., Mc Clelland, N., Deininger, R.A., Tozer, R.G. 1970. A water quality index - do we dare. Water Sewage Works, 117, 339-343.

[9] Singh, S., Hussian, A. 2016. Water quality index development for groundwater quality assessment of Greater Noida sub-basin, Uttar Pradesh, India. Cogent Engineering, 3(1), 1177155.

[10] Tiwari, T.N., Mishra, M.A. 1985. A preliminary assignment of water quality index of major Indian river and ground water. Indian Journal of Environmental Protection, 5, 276-279.

[11] WHO. 2011. Guidelines for drinking-water quality, 4th Edition. World Health Organization, Geneva.

[12] Musa, J.J., Ahanonu, J.J. 2013. Quality assessment of shallow groundwater in some selected agrarian communities in Patigi Local Government Area, Nigeria. International Journal of Basic and Applied Sciences, 1(3), 548-563. 